\title{
Low planktic foraminiferal diversity and abundance observed in a spring 2013 west-east Mediterranean Sea plankton tow transect
}

\author{
Miguel Mallo ${ }^{1}$, Patrizia Ziveri ${ }^{1,2}$, P. Graham Mortyn ${ }^{1,3}$, Ralf Schiebel ${ }^{4}$, and Michael Grelaud ${ }^{1}$ \\ ${ }^{1}$ Institute of Environmental Science and Technology (ICTA), Autonomous University of Barcelona (UAB), \\ Bellaterra 08193, Spain \\ ${ }^{2}$ Catalan Institution for Research and Advanced Studies (ICREA), Pg. Lluís Companys 23, Barcelona 08010, Spain \\ ${ }^{3}$ Geography Department, UAB, Bellaterra 08193, Spain \\ ${ }^{4}$ Climate Geochemistry, Max Planck Institute for Chemistry, Hahn-Meitner-Weg 1, 55128 Mainz, Germany \\ Correspondence to: Patrizia Ziveri (patrizia.ziveri@uab.cat) and Miguel Mallo (miguel.mallo@e-campus.uab.cat)
}

Received: 21 June 2016 - Discussion started: 14 July 2016

Revised: 7 March 2017 - Accepted: 12 March 2017 - Published: 4 May 2017

\begin{abstract}
Planktic foraminifera were collected with $150 \mu \mathrm{m}$ BONGO nets from the upper $200 \mathrm{~m}$ water depth at 20 stations across the Mediterranean Sea between 2 May and 2 June 2013. The main aim is to characterize the species distribution and test the covariance between foraminiferal area density $\left(\rho_{\mathrm{A}}\right)$ and seawater carbonate chemistry in a biogeochemical gradient including ultraoligotrophic conditions. Average foraminifera abundances are $1.42 \pm 1.43$ ind $10 \mathrm{~m}^{-3}$ (ranging from 0.11 to 5.20 ind $10 \mathrm{~m}^{-3}$ ), including 12 morphospecies. Large differences in species assemblages and total abundances are observed between the different Mediterranean sub-basins, with an overall dominance of spinose, symbiont-bearing species indicating oligotrophic conditions. The highest values in absolute abundance are found in the Strait of Gibraltar and the Alboran Sea. The western basin is dominated by Globorotalia inflata and Globigerina bulloides at slightly lower standing stocks than in the eastern basin. In contrast, the planktic foraminiferal assemblage in the warmer, saltier, and more nutrient-limited eastern basin is dominated by Globigerinoides ruber (white). These new results, when combined with previous findings, suggest that temperatureinduced surface water stratification and food availability are the main factors controlling foraminiferal distribution. In the oligotrophic and highly alkaline and supersaturated with respect to calcite and aragonite Mediterranean surface water, standing stocks and $\rho_{\mathrm{A}}$ of $G$. ruber (white) and G. bulloides are affected by both food availability and seawater carbonate chemistry. Rapid warming increased surface ocean stratifica-
\end{abstract}

tion impacting food availability and changes in trophic conditions could be the causes of reduced foraminiferal abundance, diversity, and species-specific changes in planktic foraminiferal calcification.

\section{Introduction}

The single-celled foraminifera comprise the most diverse group of calcareous zooplankton of the modern ocean. The majority of foraminifer species are benthic. About 50 morphospecies are planktic, which have a calcareous test organized in chambers (e.g., d'Orbigny, 1826; Hemleben et al., 1989; Goldstein, 1999). The species from different environments can be characterized by differences in wall structure, pore size and spatial density, spines, and test shape, which are partly related to adaptation. The distribution of foraminifera is thought to be influenced by food availability, temperature, salinity, turbidity, sunlight, and predation; these factors provoke an overall water depth preference, which shifts during ontogeny, and seasonal preference for each species (e.g., Rebotim et al., 2017; Schiebel and Hemleben, 2005; Hemleben et al., 1989). Some species are found only in the photic zone because they are symbiont-bearing and depend on light for photosynthesis. After reproduction, the empty shells sink to the seafloor, where the fossils are useful for paleoceanographic studies (e.g., Shackleton, 1968; Rohling et al., 2004; Mojtahid et al., 2015). Ecological tolerance limits of modern foraminifera are not completely defined, but progressive 
reduction in abundance (caused by worsening of their organic functions, such as food uptake, growth, and reproduction, until death) is related with their departure from optimum conditions (Bé, 1977; Arnold and Parker, 1999). The absolute abundance of foraminifera is also affected by a predictable and distinct seasonal cycle for each species driven by the food content and temperature of the water mass (Hemleben et al., 1989; Bé and Tolderlund, 1971; Jonkers and Kučera, 2015; Žarić et al., 2005; for Mediterranean examples see Pujol and Vergnaud Grazzini, 1995; Bárcena et al., 2004; Hernández-Almeida et al., 2011; Rigual-Hernández et al., 2012; de Castro Coppa et al., 1980).

A vast majority of studies on planktic foraminifera are based on samples from bottom sediments and sediment cores, mainly for paleoceanographic purposes, with few studies considering the modern population in the water column, including the Mediterranean Sea. The first modern study of planktic foraminifera in this specific area was based on surface sediment samples collected by the Swedish DeepSea expedition of 1947-1948 (Pettersson, 1953). A subsequent study found different species assemblages between the western basin, the eastern basin, and the Aegean Sea (Parker, 1955). The pioneering study of foraminifera population variability in the water column of the Mediterranean was conducted by Glaçon et al. (1971) in the Ligurian Sea, showing large seasonal variations of the relative abundances of the different species. Such variations of planktic foraminiferal assemblages in the water column were also reported for the Bay of Naples (de Castro Coppa et al., 1980). Cifelli (1974) was the first to cover the broader Mediterranean, with plankton tows of the upper $250 \mathrm{~m}$ of the water column from west Madeira in the Atlantic Ocean to the Isle of Rhodes in June 1969; they identified different relative abundances of subtropical and subpolar species in different parts of the Mediterranean.

Thunell (1978) studied the upper $2 \mathrm{~cm}$ of sediment cores retrieved from different sites of the Mediterranean Sea and concluded that the distribution of planktic foraminifera was closely related to the distribution of the different surface water masses. Each water mass has a characteristic range of temperature and salinity (Brown et al., 2001) and a partial isolation effect in the different basins and sub-basins of the Mediterranean. Those hydrographic differences result in different species assemblages in each region. This contradicts somewhat with Pujol and Vergnaud Grazzini (1995), who gained quantitative data with flow-metered plankton tows in the upper $350 \mathrm{~m}$ of the water column, through a northwest-southeast (NW-SE) Mediterranean transect from September-October 1986 and February 1988, and the Alboran Sea in April 1990. They concluded that despite the W-E temperature and salinity gradients observed, those were not large enough and no close correlation was found to justify the extremely variable foraminifera assemblages, with high seasonal and geographical variations in absolute and relative abundances. They suggested that food availability is the main factor controlling their seasonal and geographical distribution and abundance. Hydrographic structures like eddies and fronts exert control on the distribution of species in case food is present in ample amounts.

Despite no recent plankton tow study being carried out in the entire Mediterranean Sea, three regional studies based on sediment traps were realized in the Alboran Sea (Bárcena et al., 2004; Hernández-Almeida et al., 2011) and the Gulf of Lion (Rigual-Hernández et al., 2012). The 1-year time series study of the Alboran Sea sediment traps (July 1997May 1998) shows big differences in the main species distribution and daily export production, driven by food availability (related with water mixing/stratification periods) and temperature (Bárcena et al., 2004; Hernández-Almeida et al., 2011). The 12-year sediment trap foraminifera flux record in the Gulf of Lion (October 1993-January 2006) shows a strong seasonal pattern, with more than $80 \%$ of the annual export production recorded from winter to spring related to higher food supply and mixing state of the water column (Rigual-Hernández et al., 2012).

The calcification of foraminifera is affected by the chemical state of ambient seawater. Theoretically, their shell mass is positively related to temperature, $\mathrm{pH},\left[\mathrm{Ca}^{2+}\right]$, alkalinity, and $\left[\mathrm{CO}_{3}^{2-}\right]$, and negatively related to the $\left[\mathrm{CO}_{2}\right]$ of ambient seawater (Schiebel and Hemleben, 2005). Different studies conducted on water column foraminifera show differential results, as their shell mass can either be positively (Aldridge et al., 2012; Beer et al., 2010a; Marshall et al., 2013; Moy et al., 2009) or negatively related to $\left[\mathrm{CO}_{2}\right]$ (Beer et al., 2010a). Also, other studies report a positive effect of the temperature on foraminifera shell mass (Mohan et al., 2015; Aldridge et al., 2012; Marshall et al., 2013; Weinkauf et al., 2016). Beer et al. (2010a) suggested a species-specific relation between shell mass and $\left[\mathrm{CO}_{3}^{2-}\right]$, depending on the presence or absence of symbionts. Some authors suggest that other factors like ecological stress do not affect the calcification intensity (Weinkauf et al., 2013). For further studies that relate foraminiferal calcification with environmental parameters see Weinkauf et al. (2016); Table 7. From the onset of the industrial era, anthropogenic emissions of $\mathrm{CO}_{2}$ have led to ocean acidification, decreasing seawater $\mathrm{pH}$ and $\left[\mathrm{CO}_{3}^{2-}\right]$, which provokes reduced stability of $\mathrm{CaCO}_{3}$ that may reduce the formation of foraminiferal test calcite (Zeebe, 2012; de Moel et al., 2009; Moy et al., 2009).

Studies of the ecology of foraminifera in the Mediterranean waters remain scarce. Few studies exist covering the entire Mediterranean Sea. Most studies are focused on specific regions, e.g., the Gulf of Naples (de Castro Coppa et al., 1980) or the Alboran Sea plus the southwestern Mediterranean (van Raden et al., 2011). Data on living planktic foraminiferal abundances are provided by Cifelli (1974; spring only) and more recently by Pujol and Vergnaud Grazzini (1995). In addition, few size-normalized weight (SNW) and area density $\left(\rho_{\mathrm{A}}\right)$ studies to infer the calcification intensity of water column foraminifera are available in the litera- 
ture (see Schiebel et al., 2007; Beer et al., 2010a; Aldridge et al., 2012; Marshall et al., 2013, 2015; Mohan et al., 2015; Weinkauf et al., 2016). New data are needed, since environmental conditions of the water column and associated foraminiferal assemblages might have changed over the past 20 years.

In this study, new quantitative and qualitative data are presented on living planktic foraminifera across the Mediterranean Sea during spring 2013. Comparisons are made with previous studies from Pujol and Vergnaud Grazzini (1995), Cifelli (1974), de Castro Coppa et al. (1980), Bárcena et al. (2004), Hernández-Almeida et al. (2011), RigualHernández et al. (2012), and Thunell (1978). The study by Thunell (1978) is based on surface sediments, but might be biased by differential transportation and dissolution of tests (Thunell, 1978; Caromel et al., 2014; Schiebel et al., 2007). Although core top samples $(0-2 \mathrm{~cm})$ are suitable to infer variability of modern conditions (Thunell, 1978), they may cover the last few decades to few centuries, depending on the sedimentation rate, while our plankton tow sampling represents a "snap shot" of the modern water column (Mortyn and Charles, 2003), in this case the Mediterranean. Correlated results between plankton tows (Pujol and Vergnaud Grazzini, 1995) and surface sediments (Vergnaud Grazzini et al., 1986) at coincident places in the Mediterranean confirm the results obtained by Thunell (1978).

The objectives here are to (1) delineate new absolute abundances of planktic foraminifera within the different regions of the Mediterranean Sea during spring, (2) characterize ecological demands at the species level by comparison with previous studies, and (3) provide new $\rho_{\mathrm{A}}$ data for comparisons between sub-basins of the Mediterranean Sea and with other studies, in the context of ocean warming and acidification over the past 20 to 40 years.

\section{Oceanographic setting}

The Mediterranean Sea, with a strong thermohaline and wind-driven circulation, and a surface of approximately $2500000 \mathrm{~km}^{2}$, is divided into two main basins near the Strait of Sicily: the western and eastern basins. These basins are composed of different sub-basins due to partial isolation caused by sills that influence the water circulation, and by different water properties (Rohling et al., 2015, 2009). Their natural connection with the ocean is through the narrow Strait of Gibraltar, where nutrient-rich Atlantic surface waters enter the Mediterranean and experience an eastward increase of temperature and salinity (Fig. 1) driven by insolation and evaporation, having a negative hydrological balance (evaporation exceeding precipitation). The Mediterranean becomes increasingly oligotrophic towards the east (Figs. 1, 2). In addition, the incoming Atlantic waters enter the AlgeroProvençal Basin as far as the Tyrrhenian Sea, and contribute to deep-water formation in the Gulf of Lion in cold winters (Rohling et al., 2015, 2009).

In the eastern basin, two main sources of deep-water formation are active mainly during winter in the Adriatic and the Aegean Seas. Cold dry winds cause evaporation and cooling forming denser and more saline water masses that sink to depth (Rohling et al., 2015, 2009; Hassoun et al., 2015b). The same process is active in the Levantine basin, forming an intermediate water mass, which becomes progressively cooler and fresher toward the western basin. Some waters reach the Tyrrhenian Sea. Waters returning to the Atlantic through the Strait of Gibraltar at depth are cooler and saltier than the inbound waters, and compensate for the inflow from the Atlantic. The Mediterranean Sea has a large physicochemical gradient for such a small marginal sea (Rohling et al., 2015, 2009; Fig. 1).

\section{Methodology}

\subsection{Study area}

Plankton tow samples were collected during the MedSeA (Mediterranean Sea Acidification in a Changing Climate) cruise from 2 May to 2 June 2013 onboard the Spanish $\mathrm{R} / \mathrm{V}$ Ángeles Alvariño. The transect was divided into two legs (Fig. 2). The first leg ranged from the Atlantic Ocean near the Gibraltar Strait (adjacent to Cadiz Harbour, Spain) as far as the Levantine sub-basin in the eastern Mediterranean (3879 km long, 11 sampling sites). The second leg started from Heraklion (Crete, Greece) into the Ionian Sea, passed south of the Adriatic and Tyrrhenian Seas, and ended in the northern Algero-Provençal basin, adjacent to Barcelona, Spain (3232 km long, 9 sampling sites, Fig. 2).

\subsection{Material and methods}

In total 20 samples were collected down to $200 \mathrm{~m}$ water depth with BONGO nets (Table 1), with mesh sizes of $150 \mu \mathrm{m}$, and $40 \mathrm{~cm}$ diameter (for further details see Posgay, 1980). The sampling device was equipped with a flow meter allowing the estimation of the volume filtered in each tow. The data for temperature, salinity, oxygen, and fluorescence were integrated over the upper $200 \mathrm{~m}$ from the nearest conductivitytemperature-depth (CTD) stations retrieved during the same cruise (for the complete data set see Ziveri and Grelaud, 2015). Seawater carbonate data (total alkalinity (AT), and dissolved inorganic carbon (DIC)) were obtained from water samples retrieved at various depths during the CTD casts (see Goyet et al., 2015). These data were used to calculate $\mathrm{pH}, p \mathrm{CO}_{2}$, and $\left[\mathrm{CO}_{3}^{2-}\right]$ using the software CO2Sys (Lewis et al., 1998) with the equilibrium constants of Mehrbach (1973) refitted by Dickson and Millero (1987). These three parameters of the carbonate system were then integrated for the upper $200 \mathrm{~m}$ water depth. The nutrient concentrations $\left(\left[\mathrm{PO}_{4}\right]\right.$ and $\left[\mathrm{NO}_{3}\right]$ ) were measured by OGS (Italian National Insti- 

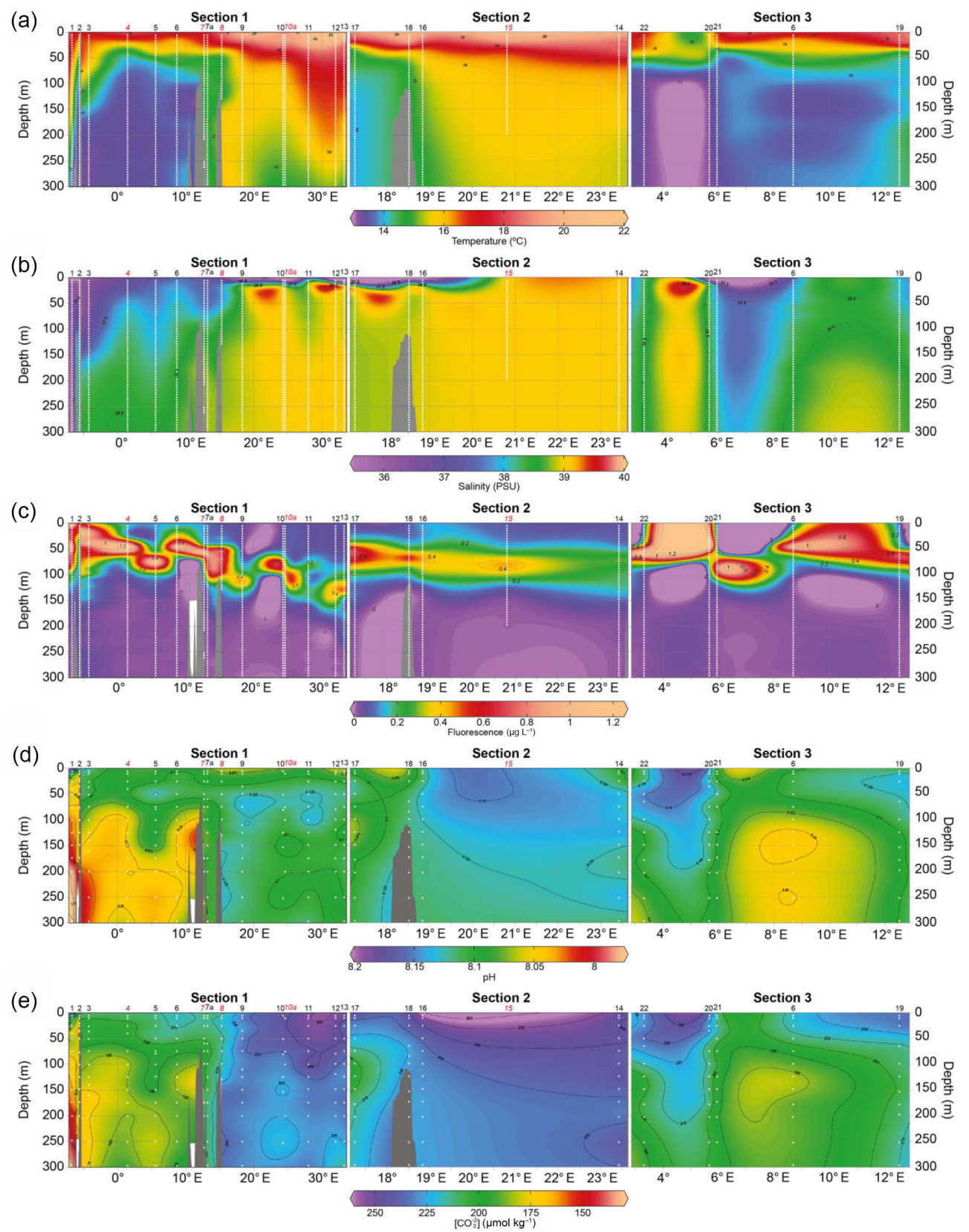

(f)

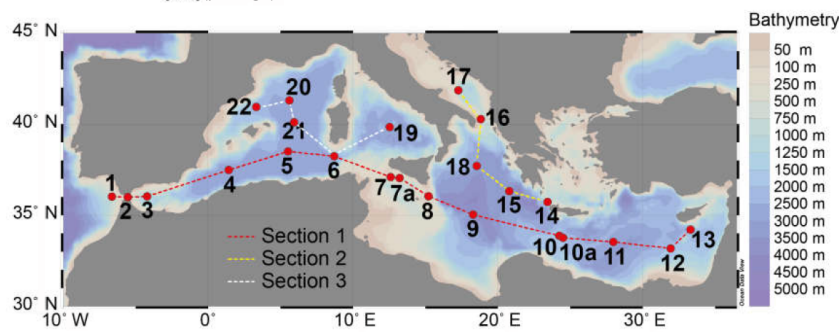

Figure 1. (a) Temperature $\left({ }^{\circ} \mathrm{C}\right)$, (b) salinity, (c) fluorescence $\left(\mu \mathrm{g} \mathrm{L}{ }^{-1}\right)$, (d) $\mathrm{pH}$, and (e) $\left[\mathrm{CO}_{3}^{2-}\right]\left(\mu \mathrm{mol} \mathrm{kg}{ }^{-1}\right)$ values of the water column of the transect. Values follow a color scale (under every graph), also values shown in the isometric lines; $x$ axis: water depth; $y$ axis: longitude (degrees). Measurement locations indicated with white dots, with the coinciding stations numbered at top. The station number and the map section are shown on the map (f). For station code names see Table 1. Note reversed color scale at (d, e). Software used: Ocean Data View (Schlitzer, 2016). 


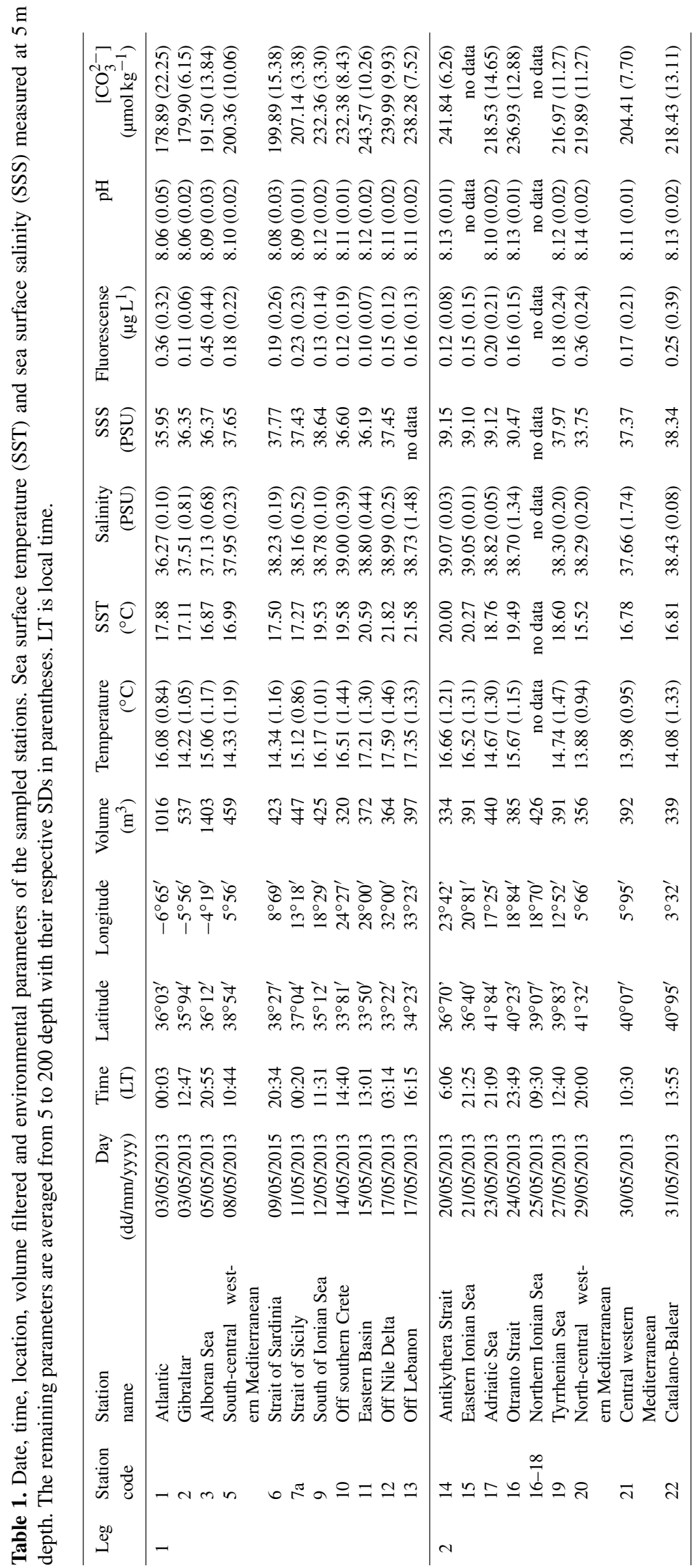




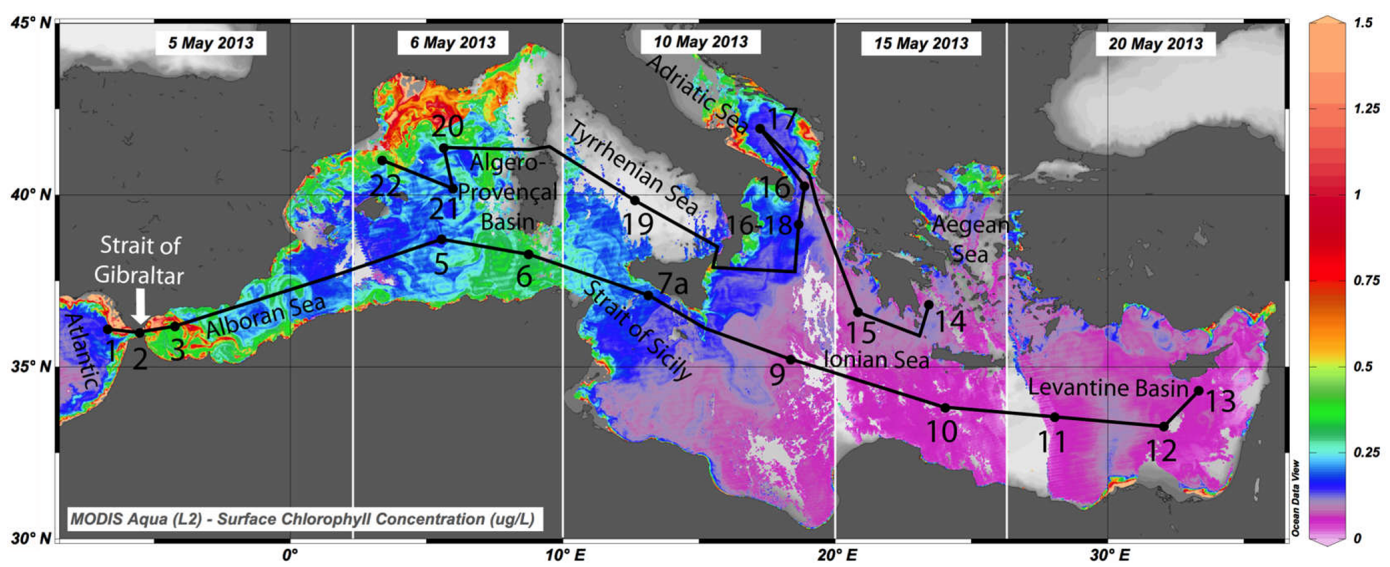

Figure 2. Sampled stations with BONGO nets (dots). The numbers in the picture represent the station codes: first transect - 1 to 13 , second transect -14 to 22 . For station code names see Table 1. Color scale at right represents the values of surface chlorophyll concentration (in $\mu \mathrm{L} \mathrm{L}^{-1}$ ), retrieved from MODIS Aqua (L2), from the closest day as possible of the first transect, specified in the upper part.

tute of Oceanography and Experimental Geophysics). The water samples were filtered on glass fiber filters (Whatman $\mathrm{GF} / \mathrm{F} ; 0.7 \mu \mathrm{m})$ and then kept at $-20^{\circ} \mathrm{C}$ onboard. The samples were then analyzed in the laboratory with a Bran+Luebbe3 AutoAnalyzer (see Grasshoff et al., 1999). A surface chlorophyll $a$ concentration was obtained from MODIS Aqua L2 satellite data (NASA Goddard Space Flight Center, 2013).

Foraminiferal samples were collected either at daytime or nighttime. Plankton samples were preserved by adding a $4 \%$ formaldehyde solution buffered with hexamethyltetramine at $\mathrm{pH}=8.2$ onboard. Individuals were not necessarily alive when collected and no distinction was made between cytoplasm-bearing tests: as alive or dead but still containing cytoplasm (see also Boltovskoy and Lena, 1970), and empty tests (dead) were considered for this study. From each sampling station, the foraminifera were isolated and identified at the species level. When necessary, samples were split into aliquots of one-fourth and one-sixth. For each sample, each species was counted and isolated according to three size fractions $(150-350,350-500$, and $>500 \mu \mathrm{m})$ to determine the absolute and relative abundances. Foraminifera smaller than $150 \mu \mathrm{m}$ and/or with tests partially broken, making them unrecognizable or unmeasurable, were discarded.

We classified the different foraminifera species by visual identification using incident light microscopy. Following the morphometric guidelines and taxonomic nomenclature proposed by Aurahs et al. (2011) for Globigerinoides ruber (white), Globigerinoides ruber (pink), and Globigerinoides elongatus. For Trilobatus sacculifer (with sac) and T. sacculifer (without sac) we followed Spezzaferri et al. (2015). The taxonomy of Hemleben et al. (1989) was applied to classify Globigerina bulloides, Orbulina universa, Globorotalia inflata, Globorotalia menardii, and Hastigerina pelagica. Trilobatus sacculifer morphotype quadrilobatus was inferred from Spezzaferri et al. (2015) after André et al. (2013); this morphotype is referred as T. quadrilobatus in this study and is treated separately from $T$. sacculifer (without sac). The Globigerinella siphonifera-G. calida-G. radians plexus (see Weiner et al., 2015) is treated as G. siphonifera in our study.

For the area density $\left(\rho_{\mathrm{A}}\right)$ study, we selected three main species: G. ruber (white), G. bulloides, and O. universa. All specimens, without partially broken tests and/or with organic matter attached, of these three species were photographed with a Canon EOS $650 \mathrm{D}$ camera device attached to a Leica Z16 AP0 microscope to measure their long axis and silhouette area using the software ImageJ (Schneider et al., 2012). For each station and each of the three selected species, the individuals were weighed together by triplicate with a Mettler Toledo XS3DU microbalance $( \pm 1 \mu \mathrm{g}$ of nominal precision) within $50 \mu \mathrm{m}$ size fraction increments (150-200, 200-250 $\mu \mathrm{m}$, etc.). Cytoplasm-filled or empty dry-weighed foraminifera tests were weighted together since dry cytoplasm has no statistically significant effect on the weight of tests $>150 \mu \mathrm{m}$ (Schiebel et al., 2007). Specimens containing notable organic matter attached to the outside of the test were discarded. The maximum number of individuals weighed together was five. At some stations, individuals were measured individually in case more than one specimen was not available. In all cases, the mean weight per specimen of the three weightings was applied (cf. Beer et al., 2010b; Movellan et al., 2012). The silhouette area obtained was then used to calculate the $\rho_{\mathrm{A}}$ (Weinkauf et al., 2013; Marshall et al., 2013, 2015).

\subsection{Statistical methods}

Principal component analysis (PCA; varimax rotation) of the environmental parameters (temperature, salinity, oxygen, fluorescence, $\mathrm{NO}_{3}, \mathrm{PO}_{4}, \mathrm{pH}, p \mathrm{CO}_{2}$, and $\mathrm{CO}_{3}^{2-}$ ) characterizing the 20 stations was extracted using SPSS Statistic 23 software. The two first PCA factors explain about $77 \%$ of the total variance in environmental parameters (Fig. 3). The first 
Table 2. Loadings of the environmental parameters in the PCA and additional Pearson correlation coefficients $(r)$ for relationships between other variables and PCA factors $(n=20)$ and the results for the abundances of $G$. ruber (white) $(n=13)$, T. sacculifer (without sac) $(n=13)$, G. bulloides $(n=16), G$. inflata $(n=10)$, O. universa $(n=17)$, and the total abundances $(n=20)$; and the area density of $G$. bulloides $(n=16), G$. ruber (white) $(n=13)$, and $O$. universa $(n=17) . r$ values in bold are significant at $p<0.05,{ }^{*} p<0.1$.

\begin{tabular}{|c|c|c|c|c|c|c|c|c|c|c|c|}
\hline & \multicolumn{2}{|c|}{ PCA results } & \multicolumn{6}{|c|}{ Abundances } & \multicolumn{3}{|c|}{ Area density } \\
\hline & Factor 1 & Factor 2 & $\begin{array}{l}\text { G. ruber } \\
\text { (white) }\end{array}$ & $\begin{array}{l}\text { T. sacculifer } \\
\text { (without sac) }\end{array}$ & G. bulloides & G. inflata & O. universa & TOTAL & G. bulloides & $\begin{array}{r}\text { G. ruber } \\
\text { (white) }\end{array}$ & O. universa \\
\hline Factor 1 & 1 & & -0.297 & 0.353 & 0.511 & 0.242 & 0.009 & 0.309 & -0.369 & 0.324 & -0.449 \\
\hline Factor 2 & 0 & 1 & 0.121 & -0.549 & -0.470 & -0.209 & -0.127 & -0.406 & 0.279 & -0.296 & 0.133 \\
\hline \multicolumn{12}{|c|}{ Environmental factor loadings } \\
\hline Temperature & -0.825 & -0.030 & $0.346^{*}$ & -0.158 & $-0.333^{*}$ & -0.154 & -0.198 & -0.154 & 0.294 & $-0.324^{*}$ & 0.464 \\
\hline Salinity & -0.777 & 0.532 & 0.296 & $-0.353^{*}$ & $-0.425^{*}$ & -0.479 & -0.005 & $-0.393^{*}$ & $0.346^{*}$ & -0.721 & $0.355^{*}$ \\
\hline Oxygen & -0.084 & 0.602 & -0.149 & -0.675 & -0.684 & -0.241 & 0.042 & -0.682 & 0.050 & 0.072 & 0.509 \\
\hline Fluorescence & 0.721 & -0.185 & $-0.378^{*}$ & -0.101 & -0.020 & 0.459 & -0.063 & 0.028 & -0.275 & 0.738 & -0.246 \\
\hline$\left[\mathrm{NO}_{3}\right]$ & 0.912 & -0.113 & $-0.344^{*}$ & 0.460 & 0.567 & 0.166 & -0.063 & 0.290 & -0.295 & 0.156 & -0.548 \\
\hline$\left[\mathrm{PO}_{4}\right]$ & 0.893 & -0.272 & $-0.361^{*}$ & 0.461 & 0.579 & 0.293 & -0.168 & $0.340^{*}$ & -0.264 & 0.252 & -0.538 \\
\hline $\mathrm{pH}$ & -0.189 & 0.969 & 0.215 & -0.559 & -0.563 & $-0.351^{*}$ & 0.117 & -0.448 & 0.263 & $-0.381^{*}$ & 0.236 \\
\hline$p \mathrm{CO}_{2}$ & 0.086 & -0.941 & -0.170 & $0.589^{*}$ & 0.554 & 0.196 & -0.160 & $0.378^{*}$ & -0.167 & 0.154 & -0.177 \\
\hline$\left[\mathrm{CO}_{3}^{2-}\right]$ & -0.594 & 0.729 & $0.352^{*}$ & -0.451 & -0.566 & -0.452 & -0.016 & -0.447 & $0.406^{*}$ & -0.614 & 0.434 \\
\hline & $n=20$ & $n=20$ & $n=13$ & $n=13$ & $n=16$ & $n=10$ & $n=17$ & $n=20$ & $n=16$ & $n=13$ & $n=17$ \\
\hline
\end{tabular}

factor exhibited positive loadings on the nutrients and the fluorescence and negative loadings on temperature and salinity (and to a lesser degree on $\left[\mathrm{CO}_{3}^{2-}\right]$; Table 2). The first factor explains $56.99 \%$ of the total variance and depicts well the general trend observed in the Mediterranean Sea with in general colder and more productive waters in the western basin and warmer and less productive waters in the eastern one. The second factor explains about $20.02 \%$ of the total variance and is characterized by positive loadings of $\mathrm{pH}$ and oxygen concentrations (and to a lesser degree on $\left[\mathrm{CO}_{3}^{2-}\right]$ ) and negative loading of the $p \mathrm{CO}_{2}$ (Table 2). It is interpreted as variations of the carbonate system in the Mediterranean Sea with in general lower $\mathrm{pH} /\left[\mathrm{CO}_{3}^{2-}\right]$ in the western basin compared to the eastern basin. The sample scores of the first two factors with an overlay of absolute abundances of foraminifera species (G. ruber (white), G. bulloides, G. inflata, O. universa, and T. sacculifer (without sac)) and area density (G. ruber (white), G. bulloides, and O. universa) are shown in Fig. 3.

\section{Results}

\subsection{Absolute and relative abundance}

The absolute abundance of planktic foraminifera collected with BONGO nets has a mean value of $1.42 \pm 1.43$ (SD) individuals $10 \mathrm{~m}^{-3}$. A maximum value of 5.2 ind. $10 \mathrm{~m}^{-3}$ in the Strait of Gibraltar is followed by $4.14 \mathrm{ind} .10 \mathrm{~m}^{-3}$ in the Alboran Sea, 3.61 ind. $10 \mathrm{~m}^{-3}$ in the Tyrrhenian Sea, and 3.00 ind. $10 \mathrm{~m}^{-3}$ off southern Crete (Figs. 4, 3a). With the exception of these four regions, a standing stock of 1.7 ind $10 \mathrm{~m}^{-3}$ is not surpassed at any other station. A minimum standing stock occurs in the Adriatic Sea $\left(0.11\right.$ ind. $\left.10 \mathrm{~m}^{-3}\right)$. The westernmost stations 2 and 3, with the highest Atlantic influence, have the highest abundance values ( 4.67 ind. $10 \mathrm{~m}^{-3}$ on average), followed by the eastern Mediterranean stations 9 to $13\left(1.31\right.$ ind. $10 \mathrm{~m}^{-3}$; Figs. 4, 3a; Appendix A). Pervasively, the most common size fraction of foraminifera is $150-350 \mu \mathrm{m}(65.57 \%$; Fig. 5), especially due to the presence of G. ruber (white) and G. bulloides. The 350-500 $\mu \mathrm{m}$ size fraction in the first leg dominates in the western Mediterranean and is progressively reduced eastwards (Fig. 5). Higher percentages of individuals $>500 \mu \mathrm{m}$ in the first leg are found in the western part of the Mediterranean compared to the eastern part (Fig. 5). The highest percentages of $>500 \mu \mathrm{m}$ tests are found at the Strait of Sicily and the northern Ionian Sea (station (st.) 7a, 16-18; Figs. 5, S1 in the Supplement; Appendix A). In concordance with Pujol and Vergnaud Grazzini (1995), no differences are observed between samples collected during day and night. However, due to the extremely low standing stocks the above observations are mere snapshots, and may not be generalized.

The most abundant species is G. ruber (white) (with an average of 0.30 ind $10 \mathrm{~m}^{-3}$, representing $21.49 \%$ of the total assemblage); its highest abundances are found in the Tyrrhenian Sea (st. 19, 1.69 ind. $10 \mathrm{~m}^{-3}$ ) and in the eastern Mediterranean (stations 10 and 13). Globigerinoides ruber (white) is not present in the Adriatic Sea, at station 16-18, and in the northwestern Mediterranean. It is found in low numbers in the southwestern Mediterranean, Atlantic, and Strait of Gibraltar stations (Figs. 4, 3d). Individuals $>350 \mu \mathrm{m}$ in long test axis are rare (Appendix A). G. inflata is the second most abundant species $\left(0.29\right.$ ind $\left.10 \mathrm{~m}^{-3} ; 20.19 \%\right)$, mainly due to its high abundance in the Alboran Sea (3.5 ind $10 \mathrm{~m}^{-3}$; $61.08 \%$ of the sample). It is mainly present in the western Mediterranean (Figs. 4, 3b). The dominant size fraction is $350-500 \mu \mathrm{m}$ (Appendix A). G. bulloides has an av- 

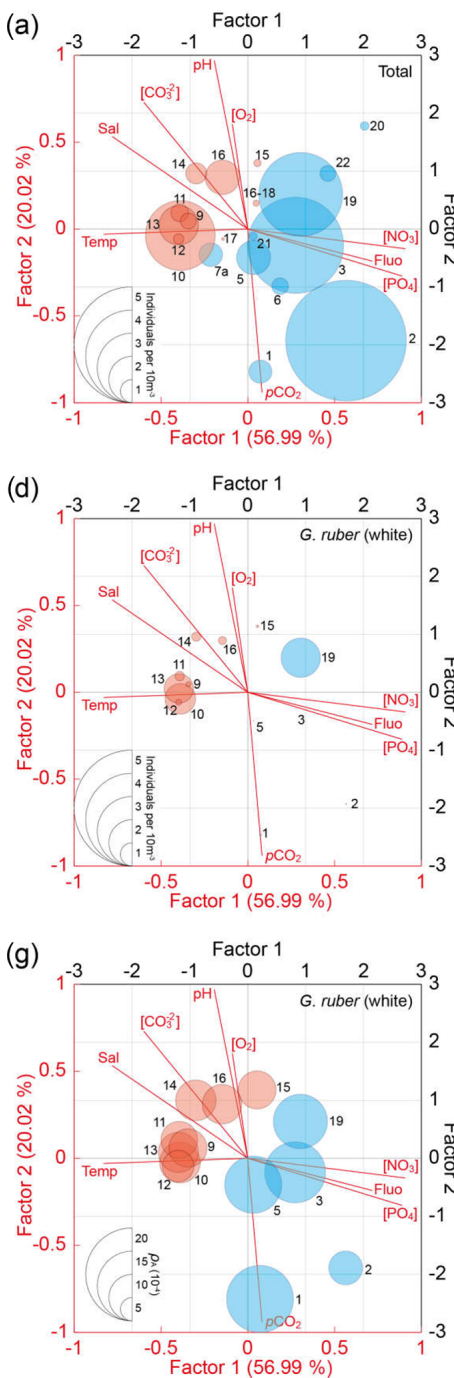
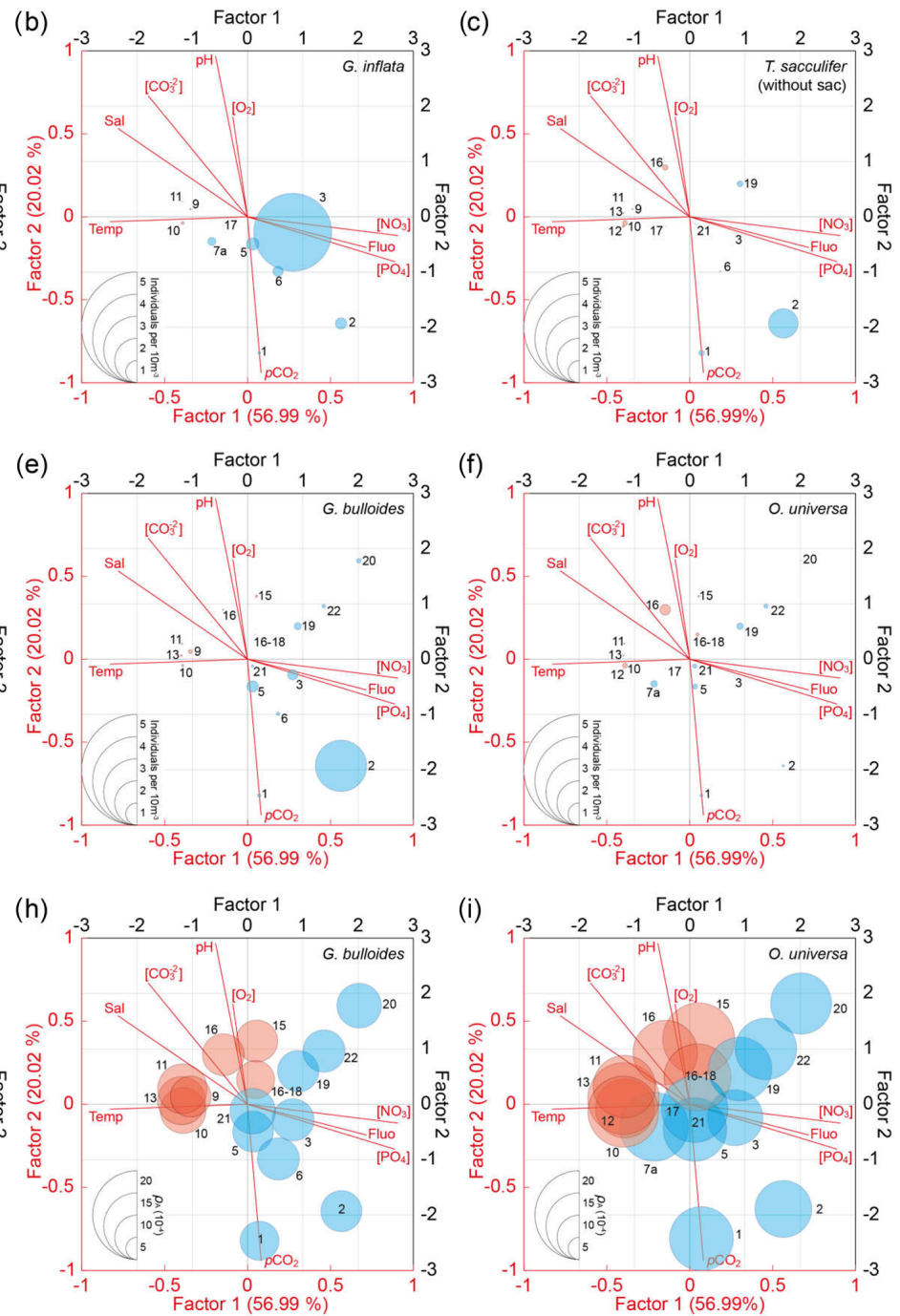

Figure 3. Sample scores on the two PCA factors with the loadings of the environmental parameters on each factor represented by the red axis. The black axis represents the overlay of the absolute abundance values (individuals $10 \mathrm{~m}^{-3}$ ) according to each station score of (a) all the foraminifera sample, (b) G. inflata, (c) T. sacculifer (without sac), (d) G. ruber (white), (e) G. bulloides, and (f) O. universa. Overlay of the area density $\left(\rho_{\mathrm{A}}\right)$ values $\left(\mu \mathrm{g} \mu^{-2}\right.$ ) of (g) G. ruber (white), (h) G. bulloides, and (i) O. universa. In blue color western Mediterranean stations (incl. Atlantic and Strait of Gibraltar), in red color the eastern Mediterranean stations.

erage abundance of 0.24 ind. $10 \mathrm{~m}^{-3}(17.20 \%)$, mainly due to its abundance in the Strait of Gibraltar $\left(2.31\right.$ ind. $10 \mathrm{~m}^{-3}$; $47.34 \%$ ). It is slightly more abundant in the southwestern Mediterranean and the Tyrrhenian Sea than in the eastern Mediterranean. It is a quite ubiquitous species being absent at four stations (Figs. 4, 3e). It rarely appears in the $>350 \mu \mathrm{m}$ test-size fraction (Appendix A).

Trilobatus sacculifer (without sac, on average 0.13 ind. $\left.10 \mathrm{~m}^{-3} ; 9.16 \%\right)$, is especially notable at the Strait of Gibraltar (50.91\%; Figs. 4, 3c). O. universa is ubiquitous in the whole Mediterranean Sea with the exception of the three stations (st. 6, 9, and 14; Figs. 4, 3f). Its average abundance is 0.12 ind $10 \mathrm{~m}^{-3}(8.70 \%)$; its dominant size fractions are $>350 \mu \mathrm{m}$ (Appendix A; Fig. 5). G. elongatus
(0.09 ind. $10 \mathrm{~m}^{-3} ; 6.41 \%$ ) is found mostly at the same stations as G. ruber (white), but is usually less abundant (Fig. 4). It is most frequent in the $350-500 \mu \mathrm{m}$ test-size fraction, and some individuals $>500 \mu \mathrm{m}$ are found in the Atlantic (Appendix A). The other species and morphotypes appear in very low numbers: T. quadrilobatus $\left(0.07\right.$ ind $\left.10 \mathrm{~m}^{-3}\right)$, G. siphonifera $\left(0.03\right.$ ind. $\left.10 \mathrm{~m}^{-3}\right), \quad$ G. ruber (pink) $\left(0.02\right.$ ind. $\left.10 \mathrm{~m}^{-3}\right), \quad H . \quad$ pelagica $\quad\left(0.008\right.$ ind $\left.10 \mathrm{~m}^{-3}\right)$, G. menardii (0.001 ind. $\left.10 \mathrm{~m}^{-3}\right)$, and T. sacculifer (with sac) (0.001,ind. $10 \mathrm{~m}^{-3}$; Fig. 4; Appendix A).

The PCA performed on the environmental parameters and the sample scores of the two first components show clear separation, between the western and eastern Mediterranean stations in factor 1 (Fig. 3). The western basin is character- 


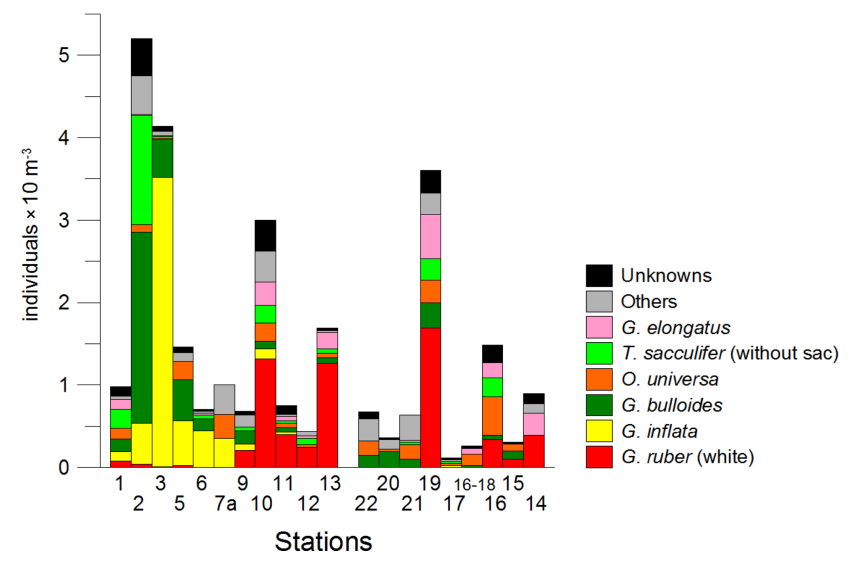

Figure 4. Absolute abundance of planktic foraminifera from BONGO nets during leg 1 (stations 1 to 13) and leg 2 (stations 22 to 14). Category "Others" is comprised of G. siphonifera-G. calidaG. radians plexus, T. quadrilobatus, H. pelagica, G. ruber (pink), G. menardii, and T. sacculifer (with sac).

ized by higher food availability to the foraminifera, lower temperatures, lower salinities, and highest absolute planktic foraminifera abundances (Fig. 3a). In the eastern basin, station 10 is an exception with a considerable contribution of G. ruber (white) to the absolute abundances (Fig. 3a). In PCA factor 2, the stations influenced by the incoming waters from the Atlantic and lowest $\left[\mathrm{CO}_{3}^{2-}\right]$ values score the highest. The stations where absolute abundances show some affinity for higher $\left[\mathrm{CO}_{3}^{2-}\right]$ values conditions are in the NW Mediterranean, the Tyrrhenian Sea, and in the northern Ionian Sea (stations 14, 15 and 16). Overall, the highest absolute abundances of the total planktic foraminifera assemblage seems to be related to food availability, and only secondarily to the carbonate system (Fig. 3a).

With the exception of the Tyrrhenian Sea (st. 19), G. ruber (white) abundance is related to warmer and saltier waters, and lower pH (st. 9, 10, 11, 12, 13, 14, 15; Fig. 3d). The opposite is observed for G. bulloides, and higher abundances occur where more food is available and at stations where $\mathrm{pH}$ is lower (Fig. 3e). O. universa shows a ubiquitous distribution with no remarkable trends within the two PCA factors (Fig. 3f). The more patchy distribution of T. sacculifer (without sac) does not follow any trend (Fig. 3c). G. inflata positively correlates with food availability, and the regional distribution follows the path of Atlantic waters (Fig. 3b).

To show the relative abundance of the various species, some stations were grouped together to achieve a minimum number of foraminifera ( $>95$ tests); the grouping was set by location proximity in which foraminiferal assemblages were similar. The stations at the Strait of Sicily and the western Mediterranean (stations 20, 21, 22) are not shown due to low numbers of individuals (<90; Fig. 6). The Tyrrhenian Sea and the eastern Mediterranean stations were dominated by G. ruber (white), and the Alboran Sea by G. inflata. The

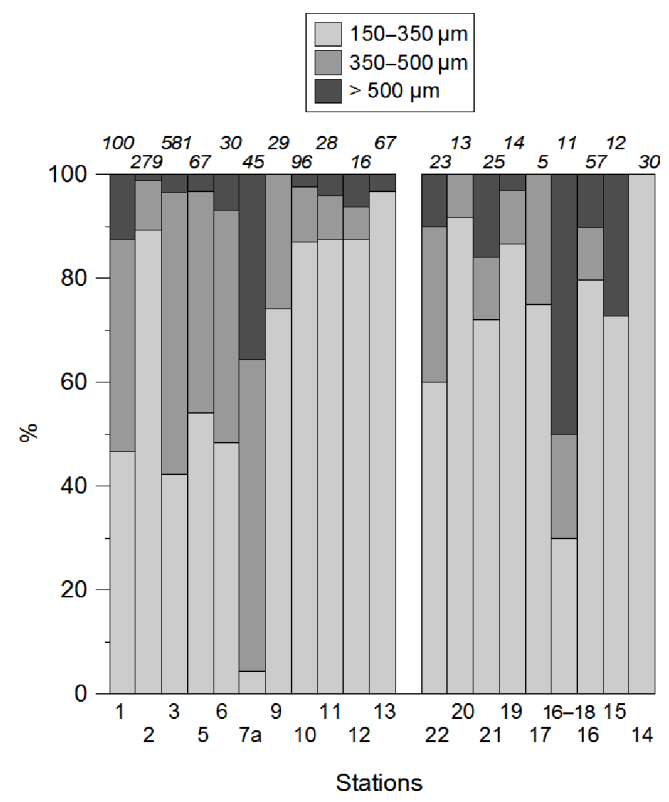

Figure 5. Percentage of each planktic foraminifera size fraction in each station from leg 1 (stations 1 to 13) and leg 2 (stations 22 to 14). Sample size is indicated in italics at the top of each station bar.

dominance of a single species in the southwestern Mediterranean is less clear, which might be due to low numbers of individuals $(G$. inflata being the main species followed by G. bulloides as in the Alboran Sea). T. sacculifer (without sac) has a high relative abundance in the Atlantic Ocean and in the Strait of Gibraltar, being the main and the second most abundant species, respectively. At all other stations analyzed, T. sacculifer (without sac) is less abundant. G. bulloides is most frequent in the entire western Basin and the Atlantic Ocean, being the main species in the Strait of Gibraltar. It is less frequent in the Tyrrhenian Sea, and in the eastern Basin and its sub-basins. G. bulloides contrasts with G. ruber (white), which always represents a small percentage of the assemblage in the western Mediterranean but dominates the Tyrrhenian Sea and the eastern Basin (Fig. 6; Appendix A).

\subsection{Area density $\left(\rho_{\mathrm{A}}\right)$}

Due to their high abundance, G. ruber (white), G. bulloides, and $O$. universa were analyzed for their area density $\left(\rho_{\mathrm{A}}\right.$; Fig. 7, including their coefficient of variation (CV); Fig. $3 g-$ i). The two-dimensional (silhouette) area-to-long axis correlation is best fitted by a power regression (Fig. S2). Similar allometric developments can be seen in G. ruber (white), $G$. bulloides, and $O$. universa with that correlation, graphically represented by the shape of a power function (Fig. S2). The allometric developments of species result from increasing size of tests when adding chambers during the successive ontogenetic stages from juvenile to adult; planktic foraminifera grow "faster" when they are younger and smaller (steepest in the lower left part of the regression line) 


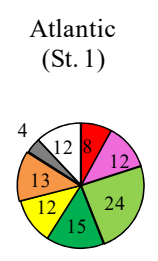

(100)

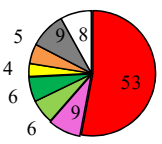

(236)
Strait of Gibraltar (St. 2)

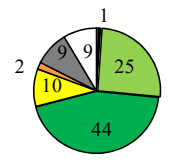

(279)

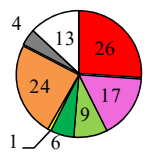

(115)

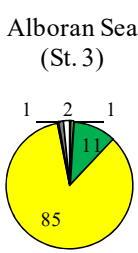

(581)

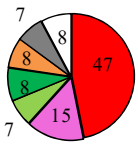

(141)
SW Mediterranean

(St. 5, 6)

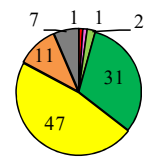

(97)

Others

G. elongatus

$T$. sacculifer (without sac)

O. universa

G. bulloides

G. inflata

G. ruber (white)

Eastern Ionian-Adriatic-Aegean Tyrrhenian Sea

Mediterranean (St. 14, 15, 17, 16,16-18) (St. 19)

(St. $9,10,11,12,13)$

Figure 6. Relative abundance of planktic foraminifera (\%). Category "Others" is comprised of G. siphonifera-G. calida-G. radians plexus, T. quadrilobatus, H. pelagica, G. ruber (pink), G. menardii and T. sacculifer (with sac). Less than $1 \%$ values are not shown. Number in parentheses indicates the total individuals of each location.

and "slower" when they are older and bigger (less steep in the upper-right part of the regression line; Fig. S2). The specimens of $G$. ruber (white) from the Atlantic have a significantly larger area than those from the Tyrrhenian Sea $(p \leq 0.003)$, which in turn have significantly larger area than those from the eastern Ionian Sea grouping ( $p \leq 0.001)$. In the other two species, G. bulloides and O. universa, a similar trend is observed regarding the two basins, with the eastern Mediterranean hosting the smallest individuals, while the largest individuals occurred in the Atlantic and the northwestern Mediterranean (Fig. S2). The different locations were grouped using the same criteria as in Fig. 6.

The long axis-to-weight relation of G. ruber (white) specimens yielded an $r^{2}=0.841$ (Fig. S3), followed by $O$. universa $\left(r^{2}=0.63\right)$, and $G$. bulloides $\left(r^{2}=0.516\right.$; Fig. S3). $O$. universa was finally discarded for comparisons between $\rho_{\mathrm{A}}$ at different locations due to a low area-weight correlation and no remarkable trend observable between locations (Figs. S4c, 3i), whereas data from G. ruber (white) correlate well (Fig. S4a). The eastern Mediterranean specimens are the lightest in both species (G. ruber (white), G. bulloides), with more extreme W-E differences in G. ruber (white) than in G. bulloides (Fig. S4d-e).

The $\rho_{\mathrm{A}}$ of $G$. ruber (white) specimens from six locations were compared (Fig. 7). The data of all the locations show a similar CV value. The eastern Mediterranean individuals have the lowest median $\rho_{\mathrm{A}}$ (approximately between $7.5 \times 10^{-5}$ and $9 \times 10^{-5} \mu \mathrm{g} \mu \mathrm{m}^{-2}$ ), with lower values eastward, and a small interquartile range $\left(\mathrm{IQR}=Q_{3}-Q_{1}\right)$. The Atlantic individuals of $G$. ruber (white) show the highest median value $\left(1.55 \times 10^{-4} \mu \mathrm{g} \mu \mathrm{m}^{-2}\right)$ and IQR. The $\rho_{\mathrm{A}}$ of Tyrrhenian individuals ranges between those from the eastern
Mediterranean and Atlantic Ocean $\left(1.2 \times 10^{-4} \mu \mathrm{g} \mu \mathrm{m}^{-2}\right)$. The $\rho_{\mathrm{A}}$ of $G$. ruber (white) for each station was compared with the two PCA factors; higher $\rho_{\mathrm{A}}$ are related to slightly lower $\mathrm{pH}$ and to higher food availability in the western Mediterranean and Atlantic stations (Fig. 3g).

For G. bulloides specimens, seven locations were compared (Fig. 7). The data from these locations show similar CV values. Specimens from the Atlantic have the lowest median $\rho_{\mathrm{A}}\left(8.75 \times 10^{-5} \mu \mathrm{g} \mu \mathrm{m}^{-2}\right)$ and the smallest IQR, showing an opposite trend than G. ruber (white). Also contrary to $G$. ruber (white), G. bulloides from the eastern Mediterranean tend to have a higher median $\rho_{\mathrm{A}}$ $\left(9.75 \times 10^{-5} \mu \mathrm{g} \mathrm{m}^{-2}\right)$ and a larger IQR. The differences in $\rho_{\mathrm{A}}$ between the eastern and western Mediterranean are smaller in $G$. bulloides than in $G$. ruber (white). The $\rho_{\mathrm{A}}$ of G. bulloides at each station was compared with the two PCA factors. Results show a less clear overall trend for $G$. bulloides than for $G$. ruber (white), with higher $\rho_{\mathrm{A}}$ associated with slightly higher $\mathrm{pH}$ in the eastern Mediterranean (Fig. 3h).

\section{Discussion}

\subsection{Abundance and diversity patterns}

Absolute abundance values of 4.2 individuals per $10 \mathrm{~m}^{-3}$ $(>150 \mu \mathrm{m})$ on average are low in comparison with earlier studies, even in oligotrophic regions. For example, in the oligotrophic northern Red Sea, less than 100 ind. $10 \mathrm{~m}^{-3}$ $(>125 \mu \mathrm{m})$ were reported from surface waters, and standing stocks were much higher than 100 ind. $10 \mathrm{~m}^{-3}$ at most of the sites sampled in 1984 and 1985 (Auras-Schudnagies et 


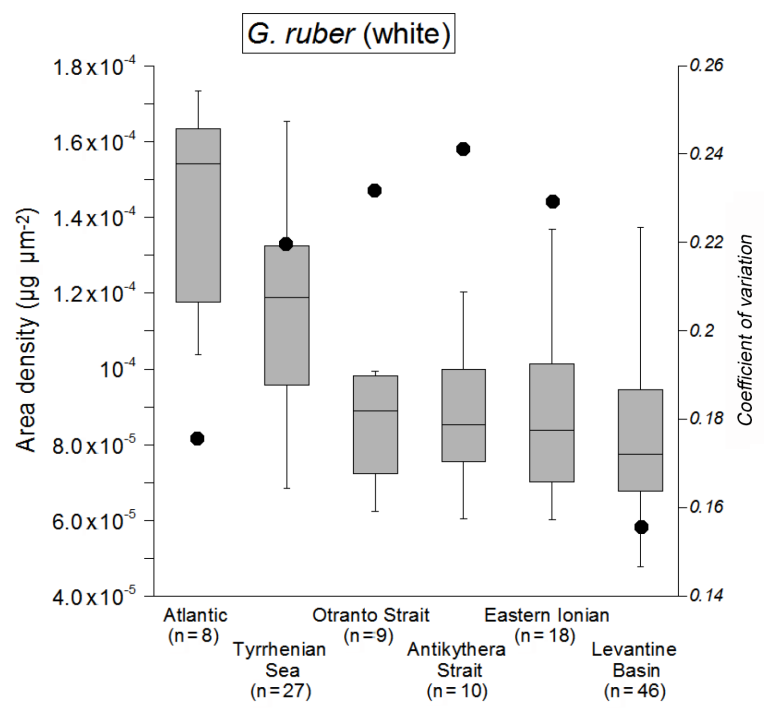

hata, 2004; Rao et al., 1991; Ottens, 1992; Schiebel et al., 1995). At higher latitudes, in the Fram Strait (Arctic Ocean), Pados and Spielhagen (2014) obtained approximate values of 117 ind. $10 \mathrm{~m}^{-3}$ from the upper $500 \mathrm{~m}$ in late June-early July of 2011. Mortyn and Charles (2003), in February-March 1996, at $200 \mathrm{~m}$ depth range in the Atlantic sector of the Southern Ocean, found as a minimum value 0.1 ind. $10 \mathrm{~m}^{-3}$, with an approximate mean of 73 ind. $10 \mathrm{~m}^{-3}$.

Within the Mediterranean, a previous study with results comparable to the data presented here, sampled the upper $350 \mathrm{~m}$ of the water column (Pujol and Vergnaud Grazzini, 1995). In the Alboran Sea, samples were obtained during a similar period of the year (April 1990) with values around 16,6 , and 9 ind $10 \mathrm{~m}^{-3}$, greater than in the station 3 (4.14 ind. $10 \mathrm{~m}^{-3}$ ). Samples from different seasons have higher abundances, with the highest values in February (Pujol and Vergnaud Grazzini, 1995), and a high annual average of 9.3 ind. $10 \mathrm{~m}^{-3}$. Regarding Pujol and Vergnaud Grazzini (1995), western Mediterranean abundances are higher than the eastern ones, due to more oligotrophic conditions and higher temperature and salinities in the east that limit foraminiferal production during winter and late summer.

Comparing with previous studies that covered the Mediterranean, we notice that Thunell (1978; surface sediments) and Pujol and Vergnaud Grazzini (1995; water column) did not find G. menardii, while the species was reported by Cifelli (1974) in very low abundances. The fact that G. menardii, which has a preference for tropical waters, is not found in the surface sediments suggests that it is a new species in the Mediterranean Sea (Cifelli, 1974). Its recent presence in the Mediterranean Sea could be related to the warming of surface waters. All other species found in our study were also found in the past studies covering the Mediterranean Sea (Cifelli, 1974; Thunell, 1978; Pujol and Vergnaud Grazzini, 1995). It remains unclear whether Thunell (1978) found G. elongatus and T. sacculifer (without sac) and classified them as G. ruber and G. sacculifer, respectively. Also, it is not certain if Cifelli (1974) found G. calida and classified it with $G$. aequilateralis (younger synonym of G. siphonifera). From the figures in Cifelli (1974), we suspect that G. elongatus was classified with $G$. ruber. In the same way, we do not find any evidence of $T$. sacculifer (with sac) from the figures presented by Cifelli (1974), but we cannot discard the possibility that this species was classified as Globigerinoides trilobus.

Trilobatus quadrilobatus was not found in any previous plankton tow studies in the Mediterranean, but is abundant in sedimentary cores (e.g., Margaritelli et al., 2016; Lirer et al., 2013; Cramp et al., 1988; Rio et al., 1990); there exists the possibility to classify it with T. sacculifer or T. trilobus in previous studies as suggested by Hemleben et al. (1989). Some species, which are absent from our samples, reached high frequencies in the aforementioned studies, e.g., Turborotalita quinqueloba, Neogloboquadrina pachyderma, and 
Globorotalia truncatulinoides. The fact that these species were not sampled in the present study may be due to their absence or presence at extremely low abundances of adult specimens at the sampled stations in May, as they present generally low abundances in spring according to a 12-year sediment trap record in the Gulf of Lion (Rigual-Hernández et al., 2012). Another possibility is their presence in test sizes smaller than $150 \mu \mathrm{m}$ (our BONGO nets). For example, Pujol and Vergnaud Grazzini (1995) used a mesh size of $120 \mu \mathrm{m}$ for sampling, which included T. quinqueloba.

To propose a quantitative comparison of the number of species found in previous studies in the Mediterranean, we used the morphospecies identified in them by the authors of each study. We identified 12 morphospecies, which is clearly less than Cifelli (1974), Thunell (1978), and Pujol and Vergnaud Grazzini (1995), reporting 18 morphospecies in total. The lower absolute abundance of individuals in our study compared to Pujol and Vergnaud Grazzini (1995), together with low species diversity in this study, may indicate a trend of changing conditions over the last decades, as it has been reported for temperature and salinity (Yáñez et al., 2010), alkalinity (Cossarini et al., 2015; Hassoun et al., 2015a), and water mass mixing (Hassoun et al., 2015b). These changing conditions could also imply changes in environmental conditions and distribution of planktic foraminifera, as discussed below; see also Field et al. (2006). Note that our mesh size is larger than that of Pujol and Vergnaud Grazzini (1995), but similar to that of Cifelli (1974), who used a mesh size of $158 \mu \mathrm{m}$. A larger mesh size would explain the lower numbers in absolute abundance and reduced diversity. In contrast, the higher diversity observed by Cifelli (1974) using a wider mesh for sampling in June supports our idea of changing ecological conditions.

The western part of the first transect (from the Atlantic to the Strait of Sicily) has a higher percentage of larger size fractions than the eastern part. The main cause of the increase in test size is a change in species composition. For example, large-sized G. inflata (especially in the 350-500 $\mu \mathrm{m}$ fraction) are present with higher abundances in the west than in the east. The same is true for the presence of large $O$. universa (especially in the $>500 \mu \mathrm{m}$ size fraction), plus the contribution of G. siphonifera, which is larger at stations where it is more frequent (Appendix A; Fig. 5).

\subsection{Factors controlling the abundance of the main species}

Abundance patterns of the five most frequent species in our samples possibly result from a combination of environmental conditions as, for example, food and temperature (Fig. 3; Table 2). The spinose and symbiont-bearing species G. ruber (white), O. universa, and T. sacculifer (without sac) mainly inhabit tropical and subtropical waters. G. ruber (white) is the main species in the Atlantic. O. universa is rather ubiquitous, and also present in warm transitional Atlantic waters
(Bé and Tolderlund, 1971). The spinose and symbiont-barren species G. bulloides tolerates a wide temperature range and is typical of subpolar and transitional regions as well as upwelling areas, it is also found in subtropical and tropical waters at lower abundances (Thunell, 1978; Bé and Tolderlund, 1971). The non-spinose species G. inflata is typical of the temperate Atlantic Ocean (Bé and Tolderlund, 1971).

\subsubsection{Globigerinoides ruber (white)}

In our study and the one by Cifelli (1974), G. ruber (white) occurs with higher abundances in the eastern compared to the western Mediterranean Basin, being the most abundant species in the Levantine Basin and the southern Ionian Sea. Furthermore, like Cifelli (1974), in our study, G. ruber (white) from the Atlantic station is found with slightly higher relative abundances than in the western Mediterranean Basin. Temperature-related factors may be the main cause, e.g., warmer Atlantic waters $\left(16.1^{\circ} \mathrm{C}\right)$ compared to the western Mediterranean $\left(14.3^{\circ} \mathrm{C}\right.$ in the $\mathrm{SW}, 14.0^{\circ} \mathrm{C}$ in the $\mathrm{NW}$; Fig. 1a). In the southern Ionian Sea and the Levantine Basin it seems that $G$. ruber (white) occurs independent of seasons, winter included, which is also true for the pink variety (see also Thunell, 1978; Pujol and Vergnaud Grazzini, 1995). The increasing dominance of $G$. ruber (white) from the western to the eastern Mediterranean Basin coincides with eastward increasing salinity and temperature (Fig. 3d; Table 2). Its higher relative abundance in the eastern basin results from the ability of G. ruber to thrive in food-depleted conditions (Hemleben et al., 1989).

G. ruber (white) remains scarce (st. 9, 14, 15) or absent (st. 16-18) in the Ionian Sea stations (Fig. 4), increasing its abundance towards the Tyrrhenian Sea. On the other hand, in the Ionian Sea, it exhibits relative abundances around $40 \%$ to more than $60 \%$ in the surface sediments (Thunell, 1978), and decreases towards the Tyrrhenian Sea. This situation could be due to higher food availability in the Tyrrhenian Sea in comparison to the Ionian Sea observed during May 2013 (Figs. 1c, 3d) plus a small difference in temperature between both seas (Figs. 1a, 3d). Also, we note that in May 1979, a scarce presence of $G$. ruber was reported in the Bay of Naples (de Castro Coppa et al., 1980), whereas in our study G. ruber is present at $47 \%$ in the Tyrrhenian Sea, being the dominant species.

The dominance of G. ruber (white) and abundance peaks in May in the eastern Mediterranean (this study), coincides with the positive temperature gradient between station 9 and station 13 (16.2-17.3 ${ }^{\circ} \mathrm{C}$; Fig. 1). In late summer, G. ruber experiences its highest abundance at warmer temperatures and more oligotrophic conditions, clearly being the main species from the north of Algeria to the Levantine Basin $(\mathrm{Pu}-$ jol and Vergnaud Grazzini, 1995). G. ruber (pink) is the dominant species at the Strait of Sicily and eastwards (Pujol and Vergnaud Grazzini, 1995), whereas in May 2013 it was rare at some locations, especially around Crete. In February, at 
low sea surface temperature, G. ruber (pink) almost disappears from the Mediterranean (Pujol and Vergnaud Grazzini, 1995; Rigual-Hernández et al., 2012). Presumably, G. ruber (white) is better adapted to lower temperatures than the pink variety. To conclude, food availability seems to be the limiting factor for the abundance of $G$. ruber once it has reached its optimum temperature range (Table 2).

\subsubsection{Globorotalia inflata}

The presence of $G$. inflata is related to cold waters and high food availability (Pujol and Vergnaud Grazzini, 1995; Rigual-Hernández et al., 2012), following high nutrient concentrations (Ottens, 1992). This explains its higher abundance in the cooler nutrient-rich western basin, and its progressive scarcity toward the warmer oligotrophic eastern Mediterranean (Fig. 1; Cifelli, 1974; Thunell, 1978). The same pattern is observed in late summer. From spring to late summer, G. inflata shows a displacement from the eastern Alboran Sea to the northwestern Mediterranean, decreasing frequency in the Algero-Provençal Basin and the southwestern Mediterranean Basin, maintaining a residual presence in the eastern basin (Pujol and Vergnaud Grazzini, 1995). In winter, at lower temperatures, the opposite process occurs, and $G$. inflata becomes the dominant species in the Alboran Sea (Bárcena et al., 2004) and the southwestern basin, with high frequencies in the Strait of Sicily and toward the Ionian Sea. Eastwards its presence is maintained at only residual levels (Pujol and Vergnaud Grazzini, 1995). Its distribution along the seasons shows that $G$. inflata is less frequent or absent in warmer, stratified, and nutrient-depleted regions of the Mediterranean than in more productive waters.

$G$. inflata is absent in the Tyrrhenian Sea, despite temperature ranges being comparable to those observed in the southwestern Mediterranean, where this species is abundant (this study). In contrast, in May 1979, G. inflata was reported in the Tyrrhenian Sea as the main species, and practically absent in the warmer summer months (de Castro Coppa et al., 1980). G. inflata is reported in sediment trap data in the Gulf of Lion (Rigual-Hernández et al. (2012), close to our northwestern Mediterranean stations (st. 20, 21, 22) at which $G$. inflata is absent. In addition, the absolute abundances of G. inflata are closely related to the PCA factor 1, suggesting a certain affinity with food availability inferred from nutrient concentrations and fluorescence data (see sample scores in Fig. 3b; Table 2). Consequently, food depletion may play a more important role in limiting the distribution of $G$. inflata than temperature.

The distribution of G. inflata during spring, with G. bulloides as a secondary species, in the Alboran Sea confirms the findings of other studies (Pujol and Vergnaud Grazzini, 1995; van Raden et al., 2011). G. inflata peak abundances appear more to the west than those reported by Cifelli (1974) to the east of the Balearic Islands. Those peaks can be asso- ciated with nutrient-rich upwelling areas rich in foraminifer prey within the temperature range of $G$. inflata (Figs. 1, 2).

\subsubsection{Globigerina bulloides}

Following Cifelli (1974), G. bulloides is the dominant species in the Atlantic close to the Strait of Gibraltar, whereas in our study it shares dominance with other species (station 1; Fig. 4). The G. bulloides dominance in the Strait of Gibraltar during late spring-early summer confirms the findings of Cifelli (1974). The abundance peak of $G$. bulloides in the Strait of Gibraltar (this study) coincides with high nutrient concentration and upwelling (Figs. 1, 2, and 4), with station 2 holding the highest standing stocks of planktic foraminifera of the whole transect analyzed here. This confirms its association with upwelling, and the production of phytoplankton as the major food source of this opportunistic species (Pujol and Vergnaud Grazzini, 1995; Sousa et al., 2014; Bárcena et al., 2004; Hernández-Almeida et al., 2011; Rigual-Hernández et al., 2012). Consequently, higher standing stocks of G. bulloides are related with higher nutrient concentration (e.g., Mortyn and Charles, 2003; Figs. 1, 3e; Table 2).

In April (Pujol and Vergnaud Grazzini, 1995; van Raden et al., 2011) and May (this study), G. bulloides is the second most abundant species, surpassed by $G$. inflata, in the westernmost Alboran Sea. High temperature anomalies could provoke an inverse situation, thanks to more suitable environmental conditions for $G$. bulloides, which profits from more successful reproduction than $G$. inflata, which instead stays further from its optimum temperature (Bárcena et al., 2004); 1 month later, G. bulloides is found to be the dominant species replacing $G$. inflata, which is still dominant in the eastern Alboran Sea (Cifelli, 1974). Its ubiquity and larger abundance in the western basin with respect to the east is supported by previous studies (e.g., Cifelli, 1974; Thunell, 1978), with a higher difference in abundance in February than in September-October (Pujol and Vergnaud Grazzini, 1995; Rigual-Hernández et al., 2012). In late summer, it decreases in numbers, with abundance peaks only around the Strait of Sicily and south of Sardinia. In winter, G. bulloides occurs at maximum relative but lower absolute abundance peaks in the Gulf of Lion, as well as in the Strait of Sicily and south of Sardinia (Pujol and Vergnaud Grazzini, 1995; Rigual-Hernández et al., 2012).

G. bulloides decreases in abundance due to food depletion in the eastern Mediterranean, where it is always less abundant than in the western basin, and more oligotrophic conditions due to water column stratification (Rigual-Hernández et al., 2012). During spring to late summer in the eastern basin, G. bulloides is less frequent, and is more abundant just east of the Strait of Sicily (Cifelli, 1974; Pujol and Vergnaud Grazzini, 1995). During winter its abundance increases and it becomes the second most abundant species in the Levantine Basin preceded by G. ruber (white), and it is also one of the main species in the Ionian Sea. Permanent ed- 
dies in the Levantine Basin sustain phytoplankton blooms, explaining the presence of G. bulloides in winter (Pujol and Vergnaud Grazzini, 1995). In the northern Levantine Basin and in the Aegean Sea, its abundances are comparable to those in the western basin regarding surface sediment data from Thunell (1978).

G. bulloides has more affinity for cooler upwelled waters than warmer more stratified waters (Sousa et al., 2014; Thunell, 1978), being present in subtropical waters only during the colder months (Ottens, 1992). The coldest station of the first leg of this study (Strait of Gibraltar, $14.2^{\circ} \mathrm{C}$ ) coincides with an abundance peak of $G$. bulloides, and it is absent from the warmest station (off the Nile Delta, $17.6^{\circ} \mathrm{C}$; Fig. 1a), which is also one of the most depleted stations in foraminiferal prey (Figs. 1c, 2). To conclude, the distribution of G. bulloides seems to be limited by food availability, caused by stratification and consequent nutrient depletion of the surface water column, and increased sea surface temperatures (Table 2).

\subsubsection{Orbulina universa}

Orbulina universa was found to be ubiquitous by Pujol and Vergnaud Grazzini (1995), being present in all the stations and seasons, reaching peak abundances in the southwestern Mediterranean both in late-summer and winter. Regarding our data, it follows the same pattern during spring, being absent from only three stations (st. 6, 9, and 14; Figs. 4, 3f). No abundance peak occurs in spring (Cifelli, 1974, and this paper) but abundances are slightly higher in the western basin than in the east. These small differences can be caused by more nutrient-rich upwelling areas (cf. Sousa et al., 2014; Morard et al., 2013) in the western basin or by higher salinities in the eastern than western basin.

\subsubsection{Trilobatus sacculifer (without sac)}

In June, T. sacculifer (without sac) has a wide distribution and represents $5 \%$ of the assemblage in the Strait of Gibraltar (Cifelli, 1974). T. sacculifer constituted up to $25 \%$ of the assemblages in May 2013, and was absent from seven stations (st. 5, 7a, 14, 15, 16-18, 20, 22). Low relative abundance occurred in April in the Alboran Sea (Pujol and Vergnaud Grazzini, 1995). In September-October T. sacculifer shows high abundances and is one of the main species from north of Minorca to the southwestern Mediterranean, and rare near the Strait of Sicily (Pujol and Vergnaud Grazzini, 1995). In late summer, it progressively decreases in numbers to the east, where G. ruber dominates assemblages (Pujol and Vergnaud Grazzini, 1995), probably due to slightly higher temperature and salinities (see also Bijma et al., 1990). On the other hand, in February T. sacculifer (without sac) disappears from the northern Levantine Basin and its abundance considerably decreases (Pujol and Vergnaud Grazzini, 1995).

\subsection{Factors controlling planktic foraminiferal test weight}

The area density $\left(\rho_{\mathrm{A}}\right)$ of tests of both $G$. ruber (white) and G. bulloides follow a systematic change from the Atlantic towards the eastern Mediterranean (Fig. 7). Therefore, the $\rho_{\mathrm{A}}$ of these two species is interpreted and discussed for possible environmental effects and biological prerequisites in the following. In contrast, the $\rho_{\mathrm{A}}$ of $O$. univers $a$ does not show any change between the western and eastern basins (Fig. 3i), and cannot be interpreted for any particular environmental effects. Unfortunately, we cannot address the effects of reproduction (e.g., Bijma et al., 1994), and ontogenetic development on the distribution patterns and test calcite mass of species, because a lack of data at the species level does not allow for any such statistics.

\subsubsection{Unknown control of the $\rho_{\mathrm{A}}$ of $O$. universa}

Since environmental and biological factors may affect individuals of the different genotypes of $\mathrm{O}$. universa to varying degrees, we could not detect any systematic change in $\rho_{\mathrm{A}}$ in the data presented here. Only one out of three genotypes of O. universa (e.g., type III, after Darling and Wade, 2008) occurs in the Mediterranean Sea (Mediterranean species, after de Vargas et al., 1999), The Mediterranean type III has been found to include two sub-types, type IIIa and type IIIb (André et al., 2014). The different genotypes and morphotypes of $O$. universa tolerate wide ranges of salinity and temperature in surface waters (e.g., de Vargas et al., 1999). Whereas the various types of $O$. universa differ in pore size (de Vargas et al., 1999; Morard et al., 2009; Marshall et al., 2015), their pore size is also affected by environmental conditions including water temperature (e.g., Bé et al., 1973). Likewise, the thickness of the test wall has been described to vary between types (de Vargas et al., 1999; Morard et al., 2009; Marshall et al., 2015), and is as well affected by environmental conditions and the ontogenetic stage of specimens. Adult $O$. universa have been shown to continuously add calcite layers to the proximal surface of the same sphere (Spero, 1988; Spero et al., 2015).

The reason why the $\rho_{\mathrm{A}}$ of $O$. univers $a$ is particularly low and highly variable in the Mediterranean despite high carbonate ion concentration $\left(\left[\mathrm{CO}_{3}^{2-}\right]\right)$ and $\mathrm{pH}$ (Fig. 1) may be found in factors other than, and in addition to, chemical and physical conditions along the transect from the Atlantic Ocean to the Levantine Basin.

\subsubsection{Factors affecting the $\rho_{\mathrm{A}}$ of $G$. ruber (white) and $G$. bulloides}

The $\rho_{\mathrm{A}}$ of G. ruber (white) is not only controlled by carbonate chemistry but also affected by other factors like food availability, similar to $O$. universa. In contrast to $O$. universa, the $\rho_{\mathrm{A}}$ data of G. ruber and G. bulloides follow systematic 
correlations. The high $\rho_{\mathrm{A}}$ of $G$. ruber in the Atlantic Ocean and Tyrrhenian Sea correlates with enhanced primary production (enhanced fluorescence, Figs. 1d, 3g; Table 2), and presumably enhanced food availability (Figs. 3g, 7, 2, also noticeable in Figs. S2d and S4d). Under more oligotrophic conditions, low $\rho_{\mathrm{A}}$ of $G$. ruber (white) might be caused by limited food availability. An opposite trend is reported for G. ruber (white) from sediment trap samples in the Madeira Basin, in which, apart from showing a negative significant correlation between calcification intensity and productivity, $\rho_{\text {A }}$ shows a positive correlation with temperature (Weinkauf et al., 2016).

The relationship between food availability and $\rho_{\mathrm{A}}$ in G. bulloides is opposite to G. ruber (white) (Figs. 3g-h, 7; Table 2). The $\rho_{\mathrm{A}}$ of $G$. bulloides tests increases from the Atlantic toward the eastern Mediterranean. In both species, larger IQRs are found toward higher absolute $\rho_{\mathrm{A}}$ (Fig. 7).

An opposite trend in $\rho_{\mathrm{A}}$ of the two species $G$. ruber (white) and $G$. bulloides had earlier been described from the Arabian Sea, and could neither be assigned to changes in $\left[\mathrm{CO}_{3}^{2-}\right]$ of ambient seawater nor growth conditions (Beer et al., 2010a). Due to its symbionts, G. ruber would rather have an advantage over symbiont-barren $G$. bulloides in oligotrophic waters, and support formation of test calcite through $\mathrm{CO}_{2}$ consumption and increasing $\left[\mathrm{CO}_{3}^{2-}\right]$ and $\mathrm{pH}$ (see also Köhler-Rink and Kühl, 2005). Those findings may still point toward differences in growth conditions; reproduction of both $G$. ruber and $G$. bulloides might be hampered under less optimal conditions, and additional calcite layers might be added to the proximal test before reproduction, similar to the process described for $O$. universa (see above). Therefore, tests may grow heavier under less than optimal food availability, given that carbonate chemistry of ambient seawater does not seem to limit the formation of test calcite in our samples.

Comparing weight-to-long axis relations, G. ruber (255$350 \mu \mathrm{m}$ size fraction) from plankton tows of the western Arabian Sea has an average weight of $11.5 \pm 0.69 \mu \mathrm{g}$ (de Moel et al., 2009), which is heavier than the individuals from our study $(5.9 \pm 0.31 \mu \mathrm{g}$; Fig. S3a; Appendix A). The difference in weight-to-long axis relation may indicate that $G$. ruber is produced under more suitable conditions for shell calcite formation in the Arabian Sea especially during non-upwelling periods and still higher overall primary productivity and food availability. However, the comparison might be biased by the fact that G. ruber (white) and G. elongatus were not separately analyzed by de Moel et al. (2009).

Data for supra-regional comparison of the weight-to-long axis relation of $G$. bulloides from the water column is possible for the $200-250 \mu \mathrm{m}$ size fraction. In the North Atlantic $\left(56-63^{\circ} \mathrm{N}\right)$, in June 2009, Aldridge et al. (2012) reported a range of $1.75-2.92 \mu \mathrm{g}\left(r^{2}=0.52\right)$. In the same size fraction, our results $\left(36^{\circ} \mathrm{N}\right)$ show heavier tests in the Alboran Sea $(3.46 \pm 0.15 \mu \mathrm{g})$, and similar weights at the Strait of Gibral$\operatorname{tar}(2.57 \pm 0.00 \mu \mathrm{g}$; Fig. S3b). For the same water depth as in our samples, Schiebel et al. (2007) found heavier average weight-to-long axis relations in fall $(5.19 \pm 0.25 \mu \mathrm{g})$ than in spring $(4.21 \pm 0.2 \mu \mathrm{g})$ in the eastern North Atlantic, and $5.51 \pm 0.31 \mu \mathrm{g}$ during the SW monsoon in the Arabian Sea. In general, higher $\rho_{\mathrm{A}}$ occurs at lower latitudes and lower $\rho_{\mathrm{A}}$ at higher latitudes (see also Schmidt et al., 2004). For G. bulloides and $G$. ruber, increased longevity and ongoing production of additional calcite layers at the proximal side of shells may result in an increased $\rho_{\mathrm{A}}$, given that seawater carbonate chemistry is only partially affecting the calcite formation in our samples.

\section{Conclusions}

Absolute and relative abundances of planktic foraminifera were studied from plankton tow samples across the Mediterranean, collected in May 2013. The samples show large differences in species abundance and assemblages between the different basins and sub-basins of the Mediterranean Sea. Absolute abundance and diversity of planktic foraminifer assemblages are low in comparison to other regions of the World Ocean. Average standing stocks in the upper $200 \mathrm{~m}$ of the water column are $1.42 \pm 1.43$ ind. $10 \mathrm{~m}^{-3}$, including 12 morphospecies in total. Planktic foraminifer assemblages are indicative of changing temperatures and salinities, as well as trophic conditions, between the eastern and the western Mediterranean Sea. The highest standing stocks of total planktic foraminifera occurred in the Strait of Gibraltar and the Alboran Sea. Overall, the largest foraminiferal tests occurred in the western Mediterranean, driven by the assemblage composition and the presence of large $G$. inflata.

Globigerinoides ruber was the most abundant species; its dominance in the east compared to the west is likely caused by stratification of the surface water column, enhanced sea surface temperature (SST), and trophic conditions. G. ruber is a symbiont-bearing species, which might be an advantage over symbiont-barren species like $G$. bulloides under oligotrophic and food-limited conditions as in the Levantine Basin. G. bulloides was more abundant in upwelled waters in the Strait of Gibraltar, in the Alboran Sea, and in the western Mediterranean. $O$. univers $a$ was present at balanced standing stocks along the entire transect from the west to the east. In general, distribution patterns of the main planktic foraminiferal species in the Mediterranean seem to be mainly related to a combination of food availability, controlled by sea surface temperature and stratification.

In the Mediterranean surface waters are supersaturated with respect to calcite and aragonite (Schneider et al., 2007; Gemayel et al., 2015). Calcification and $\rho_{\mathrm{A}}$ of the most frequent planktic foraminifera species, G. ruber (white) and G. bulloides, are largely affected by food availability. G. ruber is more affine to oligotrophic conditions, and grows the heaviest tests in less food-limited waters in the western basin near Gibraltar and in the Tyrrhenian Sea. In contrast, 
G. bulloides grows the heaviest tests under more food-limited conditions in the eastern Mediterranean Sea. We speculate that reproduction is hindered when the species-specific food sources are limited, while individuals continue adding calcite to the outer shell, and grow heavier tests than individuals that reproduced earlier in ontogeny.

These observations highlight the need for more interdisciplinary studies on the causes of changing foraminiferal assemblages and decreasing shell production, especially in the Mediterranean as a marginal basin, which is assumed particularly sensitive to changes of the environment and global climate.
Data availability. The data to this paper can be found in the Appendix and in PANGAEA (www.pangaea.de) at https://doi.pangaea. de/10.1594/PANGAEA.874300. 


\section{Appendix A}

Table A1. Planktic foraminifera data from BONGO nets: relative and absolute abundances, and weight and size parameters. The nomenclature $G$. bulloides represents the G. bulloides-G. falconensis plexus, and G. siphonifera represents the G. siphonifera-G. calida-G. radians plexus.

\begin{tabular}{|c|c|c|c|c|c|c|c|c|c|c|c|c|}
\hline Location & Atlantic & Gibraltar & $\begin{array}{r}\text { Alboran } \\
\text { Sea }\end{array}$ & 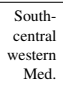 & $\begin{array}{l}\text { Strait of } \\
\text { Sardinia }\end{array}$ & $\begin{array}{r}\text { Strait of } \\
\text { Sicily }\end{array}$ & $\begin{array}{r}\text { South of } \\
\text { Ionian Sea }\end{array}$ & $\begin{array}{r}\text { Off } \\
\text { southern } \\
\text { Crete }\end{array}$ & $\begin{array}{r}\text { Eastern } \\
\text { Basin }\end{array}$ & $\begin{array}{r}\text { Off } \\
\text { Nile } \\
\text { delta }\end{array}$ & $\begin{array}{r}\text { Off } \\
\text { Lebanon }\end{array}$ & $\begin{array}{r}\text { Antikythera } \\
\text { Strait }\end{array}$ \\
\hline Station & 1 & 2 & 3 & 5 & 6 & $7 \mathrm{a}$ & 9 & 10 & 11 & 12 & 13 & 14 \\
\hline $\begin{array}{l}\text { Absolute abundance (indivi } \\
\text { Total numbers }\end{array}$ & duals $10 \mathrm{~m}$ & & & & & & & & & & & \\
\hline G. ruber (white) & 0.079 & 0.037 & 0.007 & 0.022 & 0 & 0 & 0.212 & 1.314 & 0.403 & 0.247 & 1.260 & 0.389 \\
\hline G. elongatus & 0.118 & 0.019 & 0.007 & 0 & 0.024 & 0 & 0 & 0.282 & 0.054 & 0.027 & 0.202 & 0.269 \\
\hline T. sacculifer (without sac) & 0.236 & 1.323 & 0.028 & 0 & 0.047 & 0 & 0.047 & 0.219 & 0.027 & 0.082 & 0.050 & 0 \\
\hline G. bulloides & 0.148 & 2.311 & 0.456 & 0.501 & 0.142 & 0 & 0.165 & 0.094 & 0.054 & 0 & 0.076 & 0 \\
\hline G. inflata & 0.118 & 0.503 & 3.514 & 0.545 & 0.449 & 0.358 & 0.071 & 0.125 & 0.027 & 0 & 0 & 0 \\
\hline O. universa & 0.128 & 0.093 & 0.014 & 0.218 & 0 & 0.291 & 0 & 0.219 & 0.054 & 0.027 & 0.050 & 0 \\
\hline G. siphonifera & 0.029 & 0.056 & 0.043 & 0.022 & 0 & 0.313 & 0 & 0.063 & 0 & 0 & 0.025 & 0 \\
\hline T. quadrilobatus & 0.010 & 0.335 & 0.007 & 0.087 & 0 & 0.045 & 0.118 & 0.063 & 0.027 & 0 & 0 & 0 \\
\hline $\begin{array}{l}\text { H. pelagica } \\
\text { - }\end{array}$ & 0 & 0 & 0 & 0 & 0 & 0 & 0 & 0.125 & 0 & 0.027 & 0 & 0 \\
\hline T. sacculifer (with sac) & 0 & 0 & 0 & 0 & 0 & 0 & 0 & 0 & 0 & 0 & 0 & 0 \\
\hline G. ruber (pink) & 0 & 0.075 & 0 & 0 & 0.024 & 0 & 0.024 & 0.125 & 0 & 0.027 & 0 & 0.120 \\
\hline G. menardii & 0 & 0 & 0 & 0 & 0 & 0 & 0 & 0 & 0 & 0 & 0 & 0 \\
\hline Unknowns & 0.118 & 0.447 & 0.064 & 0.065 & 0.024 & 0 & 0.047 & 0.375 & 0.108 & 0 & 0.025 & 0.120 \\
\hline Total & 0.985 & 5.120 & 4.141 & 1.460 & 0.709 & 1.006 & 0.683 & 3.003 & 0.753 & 0.439 & 1.689 & 0.898 \\
\hline $150-350 \mu \mathrm{m}$ size fraction & & & & & & & & & & & & \\
\hline G. ruber (white) & 0.030 & 0.037 & 0.007 & 0.022 & 0 & 0 & 0.212 & 1.314 & 0.403 & 0.247 & 1.109 & 0.389 \\
\hline G. elongatus & 0.020 & 0 & 0 & 0 & 0.024 & 0 & 0 & 0.282 & 0.054 & 0.027 & 0.202 & 0.269 \\
\hline T. sacculifer (without sac) & 0.148 & 1.174 & 0.029 & 0 & 0.047 & 0 & 0 & 0.188 & 0.027 & 0.082 & 0.050 & 0 \\
\hline G. bulloides & 0.128 & 2.199 & 0.449 & 0.415 & 0.142 & 0 & 0.165 & 0.094 & 0.054 & 0 & 0.076 & 0 \\
\hline G. inflata & 0.069 & 0.335 & 1.176 & 0.109 & 0.095 & 0.022 & 0 & 0.063 & 0 & 0 & 0 & 0 \\
\hline O. universa & 0 & 0.075 & 0.007 & 0.087 & 0 & 0 & 0 & 0.094 & 0 & 0 & 0 & 0 \\
\hline G. siphonifera & 0 & 0.019 & 0.029 & 0 & 0 & 0.022 & 0 & 0 & 0 & 0 & 0.025 & 0 \\
\hline T. quadrilobatus & 0.010 & 0.280 & 0.007 & 0.087 & 0 & 0 & 0.071 & 0.063 & 0.027 & 0 & 0 & 0 \\
\hline H. pelagica & 0 & & 0 & 0 & 0 & 0 & 0 & 0.063 & 0 & 0 & 0 & 0 \\
\hline G. ruber (pink) & 0 & 0.075 & 0 & 0 & 0.024 & 0 & 0.024 & 0.125 & 0 & 0.027 & 0 & 0.120 \\
\hline Total & 0.404 & 4.193 & 1.703 & 0.719 & 0.331 & 0.045 & 0.471 & 2.284 & 0.564 & 0.384 & 1.462 & 0.778 \\
\hline $350-500 \mu \mathrm{m}$ size fraction & & & & & & & & & & & & \\
\hline G. ruber (white) & 0.049 & 0 & 0 & 0 & 0 & 0 & 0 & 0 & 0 & 0 & 0 & 0 \\
\hline G. elongatus & 0.088 & 0.019 & 0.007 & 0 & 0 & 0 & 0 & 0 & 0 & 0 & 0 & 0 \\
\hline T. sacculifer (without sac) & 0.079 & 0.130 & 0 & 0 & 0 & 0 & 0.047 & 0.031 & 0 & 0 & 0 & 0 \\
\hline G. bulloides & 0.020 & 0.112 & 0.029 & 0.022 & 0 & 0 & 0 & 0 & 0 & 0 & 0 & 0 \\
\hline G. inflata & 0.049 & 0.149 & 2.138 & 0.414 & 0.307 & 0.313 & 0.071 & 0.031 & 0.027 & 0 & 0 & 0 \\
\hline o. universa & 0.049 & 0.019 & 0.007 & 0.109 & 0 & 0.067 & 0 & 0.125 & 0.027 & 0 & 0 & 0 \\
\hline G. siphonifera & 0.020 & 0.019 & 0.007 & 0.022 & 0 & 0.201 & 0 & 0.031 & 0 & 0 & 0 & 0 \\
\hline T. quadrilobatus & 0 & 0 & 0 & 0 & 0 & 0.022 & 0.047 & 0 & 0 & 0 & 0 & 0 \\
\hline H. pelagica & 0 & 0 & 0 & 0 & 0 & 0 & 0 & 0.063 & 0 & 0.027 & 0 & 0 \\
\hline T. sacculifer (with sac) & 0 & 0 & 0 & 0 & 0 & 0 & 0 & 0 & 0 & 0 & 0 & 0 \\
\hline G. menardii & 0 & 0 & 0 & 0 & 0 & 0 & 0 & 0 & 0 & 0 & 0 & 0 \\
\hline Total & 0.354 & 0.447 & 2.188 & 0.567 & 0.307 & 0.604 & 0.165 & 0.282 & 0.054 & 0.027 & 0 & 0 \\
\hline$>500 \mu \mathrm{m}$ size fraction & & & & & & & & & & & & \\
\hline G. ruber s.l. & 0.010 & 0 & 0 & 0 & 0 & 0 & 0 & 0 & 0 & 0 & 0 & 0 \\
\hline T. sacculifer (without sac) & 0.001 & 0.019 & 0 & 0 & 0 & 0 & 0 & 0 & 0 & 0 & 0 & 0 \\
\hline G. inflata & 0 & 0.019 & 0.135 & 0.022 & 0.047 & 0.022 & 0 & 0.031 & 0 & 0 & 0 & 0 \\
\hline O. universa & 0.079 & 0 & 0 & 0.022 & 0 & 0.224 & 0 & 0 & 0.027 & 0.028 & 0.050 & 0 \\
\hline G. siphonifera & 0.010 & 0.019 & 0.007 & 0 & 0 & 0.089 & 0 & 0.031 & 0 & 0 & 0 & 0 \\
\hline T. quadrilobatus & 0 & 0 & 0 & 0 & 0 & 0.022 & 0 & 0 & 0 & 0 & 0 & 0 \\
\hline Total & 0.108 & 0.056 & 0.143 & 0.044 & 0.047 & 0.358 & 0 & 0.063 & 0.027 & 0.027 & 0.050 & 0 \\
\hline Relative abundance (\%) & & & & & & & & & & & & \\
\hline G. ruber (white) & 8.00 & 0.72 & 0.17 & 1.49 & 0 & 0 & 31.03 & 43.75 & 53.57 & 56.25 & 74.63 & 43.33 \\
\hline G. elongatus & 12.00 & 0.36 & 0.17 & 0 & 3.33 & 0 & 0 & 9.38 & 7.14 & 6.25 & 11.94 & 30.00 \\
\hline T. sacculifer (without sac) & 24.00 & 25.45 & 0.69 & 0 & 6.67 & 0 & 6.90 & 7.29 & 3.57 & 18.75 & 2.99 & 0 \\
\hline G. bulloides & 15.00 & 44.44 & 11.02 & 34.33 & 20.00 & 0 & 24.14 & 3.13 & 7.14 & 0 & 4.48 & 0 \\
\hline G. inflata & 12.00 & 9.68 & 84.85 & 37.31 & 63.33 & 35.56 & 10.34 & 4.17 & 3.57 & 0 & 0 & 0 \\
\hline O. universa & 13.00 & 1.79 & 0.34 & 14.93 & 0 & 28.89 & 0 & 7.29 & 7.14 & 6.25 & 2.99 & 0 \\
\hline G. siphonifera & 3.00 & 1.08 & 1.03 & 1.49 & 0 & 31.11 & 0 & 2.08 & 0 & 0 & 1.49 & 0 \\
\hline T. quadrilobatus & 1.00 & 6.45 & 0.17 & 5.97 & 0 & 4.44 & 17.24 & 2.08 & 3.57 & 0 & 0 & 0 \\
\hline H. pelagica & 0 & 0 & 0 & 0 & 0 & 0 & 0 & 4.17 & 0 & 6.25 & 0 & 0 \\
\hline T. sacculifer (with sac) & 0 & 0 & 0 & 0 & 0 & 0 & 0 & 0 & 0 & 0 & 0 & 0 \\
\hline G. ruber (pink) & 0 & 1.43 & 0 & 0 & 3.33 & 0 & 3.45 & 4.17 & 0 & 6.25 & 0 & 13.33 \\
\hline G. menardii & 0 & 0 & 0 & 0 & 0 & 0 & 0 & 0 & 0 & 0 & 0 & 0 \\
\hline Unknowns & 12.00 & 8.60 & 1.55 & 4.48 & 3.33 & 0 & 6.90 & 12.50 & 14.29 & 0 & 1.49 & 13.33 \\
\hline Weight and size & & & & & & & & & & & & \\
\hline G. ruber (white) & & & & & & & & & & & & \\
\hline size fraction $(\mu \mathrm{m})$ & $250-300$ & & & & & & & $200-250$ & $200-250$ & & $200-250$ & $250-300$ \\
\hline no. of individuals & 1 & & & & & & & 4 & & & 4 & 2 \\
\hline average size $(\mu \mathrm{m})$ & 285 & & & & & & & 221 & 215.25 & & 221.5 & 281 \\
\hline average weight $(\mu \mathrm{g})$ & 4.667 & & & & & & & 1.583 & 2.417 & & 2 & 3.167 \\
\hline $\mathrm{SD}(\mu \mathrm{g})$ & 0.577 & & & & & & & 0.144 & 0.289 & & 0 & 0.577 \\
\hline size fraction $(\mu \mathrm{m})$ & $350-400$ & & & & & & & $250-350$ & $250-300$ & & $250-300$ & $300-350$ \\
\hline individuals & 4 & & & & & & & 5 & 1 & & 3 & 1 \\
\hline average size $(\mu \mathrm{m})$ & 390 & & & & & & & 267 & 261 & & 264 & 317 \\
\hline average weight $(\mu \mathrm{g})$ & 14.333 & & & & & & & 3.867 & 2.667 & & 5.111 & 6.667 \\
\hline $\mathrm{SD}(\mu \mathrm{g})$ & 0.289 & & & & & & & 0.115 & 0.577 & & 0.192 & 0.577 \\
\hline size fraction $(\mu \mathrm{m})$ & $400-450$ & & & & & & & $300-350$ & $350-400$ & & $300-350$ & \\
\hline no. of individuals & 1 & & & & & & & 3 & 1 & & 2 & \\
\hline average size $(\mu \mathrm{m})$ & 412 & & & & & & & 313.333 & 356 & & 323.5 & \\
\hline average weight $(\mu \mathrm{g})$ & 14.667 & & & & & & & 7.444 & 5.667 & & 11 & \\
\hline $\mathrm{SD}(\mu \mathrm{g})$ & 1.155 & & & & & & & 0.385 & 1.155 & & 0 & \\
\hline size fraction $(\mu \mathrm{m})$ & & & & & & & & $350-400$ & & & & \\
\hline no. of individuals & & & & & & & & 2 & & & & \\
\hline $\begin{array}{l}\text { average size }(\mu \mathrm{m}) \\
\text { a }\end{array}$ & & & & & & & & 374 & & & & \\
\hline average weight $(\mu \mathrm{g})$ & & & & & & & & 8.833 & & & & \\
\hline $\mathrm{SD}(\mu \mathrm{g})$ & & & & & & & & 0.764 & & & & \\
\hline
\end{tabular}


Table A1. Continued.

\begin{tabular}{|c|c|c|c|c|c|c|c|c|c|c|c|c|c|c|c|c|c|c|c|c|}
\hline Location & Atlantic & Gibraltar & $\begin{array}{r}\text { Alboran } \\
\text { Sea }\end{array}$ & 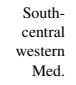 & $\begin{array}{l}\text { Strait of } \\
\text { Sardinia }\end{array}$ & $\begin{array}{c}\text { Strait of } \\
\text { Sicily }\end{array}$ & $\begin{array}{r}\text { South of } \\
\text { Ionian Sea }\end{array}$ & $\begin{array}{r}\text { Off } \\
\text { southern } \\
\text { Crete }\end{array}$ & $\begin{array}{c}\text { Eastern } \\
\text { Basin }\end{array}$ & $\begin{array}{r}\text { Off } \\
\text { Nile } \\
\text { delta }\end{array}$ & $\begin{array}{r}\text { Off } \\
\text { Lebanon }\end{array}$ & $\begin{array}{r}\text { Antikythera } \\
\text { Strait }\end{array}$ & $\begin{array}{r}\text { Eastern } \\
\text { Ionian Sea }\end{array}$ & $\begin{array}{r}\text { Adriatic } \\
\text { Sea }\end{array}$ & $\begin{array}{r}\text { Otranto } \\
\text { Strait }\end{array}$ & $\begin{array}{c}\text { Northern } \\
\text { Ionian Sea }\end{array}$ & $\begin{array}{r}\text { Tyrrhenian } \\
\text { Sea }\end{array}$ & $\begin{array}{c}\text { North- } \\
\text { central } \\
\text { western } \\
\text { Med. }\end{array}$ & $\begin{array}{r}\text { Central } \\
\text { western } \\
\text { Med. }\end{array}$ & $\begin{array}{r}\text { Catalano- } \\
\text { Balear }\end{array}$ \\
\hline Station & 1 & 2 & 3 & 5 & 6 & $7 \mathrm{a}$ & 9 & 10 & 11 & 12 & 13 & 14 & 15 & 17 & 16 & 16-18 & 19 & 20 & 21 & 22 \\
\hline $\begin{array}{l}\text { size fraction }(\mu \mathrm{m}) \\
\text { no. of individuals } \\
\text { average size }(\mu \mathrm{m}) \\
\text { average weight }(\mu \mathrm{g}) \\
\mathrm{SD}(\mu \mathrm{g})\end{array}$ & & & & & & & & & & & & & & & & & $\begin{array}{r}400-450 \\
2 \\
413 \\
16.167 \\
1.258 \\
\end{array}$ & & & \\
\hline \multicolumn{21}{|l|}{ G. bulloides } \\
\hline size fraction $(\mu \mathrm{m})$ & $300-350$ & $200-250$ & $200-250$ & $350-400$ & $300-350$ & & & & & & & & & & & & & & $400-450$ & $300-350$ \\
\hline no. of individuals & & 7 & 8 & 1 & 1 & & & & & & & & & & & & & & 1 & 3 \\
\hline average size $(\mu \mathrm{m})$ & 326.5 & 228.143 & 227.875 & 364 & 337 & & & & & & & & & & & & & & 414 & 318.333 \\
\hline average weight $(\mu \mathrm{g})$ & 4.5 & 2.571 & 3.458 & 4.667 & 4 & & & & & & & & & & & & & & 11.667 & 8.222 \\
\hline $\mathrm{SD}(\mu \mathrm{g})$ & & 0 & 0.144 & 0.577 & 1 & & & & & & & & & & & & & & 0.577 & 0.385 \\
\hline size fraction $(\mu \mathrm{m})$ & & $250-300$ & $250-300$ & & & & & & & & & & & & & & & & & $400-450$ \\
\hline no. of individuals & & & 2 & & & & & & & & & & & & & & & & & 1 \\
\hline average size $(\mu \mathrm{m})$ & & 263.75 & 270 & & & & & & & & & & & & & & & & & 441 \\
\hline average weight $(\mu \mathrm{g})$ & & 2.833 & 2.833 & & & & & & & & & & & & & & & & & 20.333 \\
\hline $\mathrm{SD}(\mu \mathrm{g})$ & & 0 & 0.289 & & & & & & & & & & & & & & & & & 1.155 \\
\hline $\begin{array}{l}\text { size fraction }(\mu \mathrm{m}) \\
\text { no of individuals }\end{array}$ & & $\begin{array}{r}300-350 \\
2\end{array}$ & $\begin{array}{r}350-400 \\
4\end{array}$ & & & & & & & & & & & & & & & & & \\
\hline average size $(\mu \mathrm{m})$ & & 310.5 & 386.5 & & & & & & & & & & & & & & & & & \\
\hline average weight $(\mu \mathrm{g})$ & & 4.5 & 9.667 & & & & & & & & & & & & & & & & & \\
\hline $\mathrm{SD}(\mu \mathrm{g})$ & & 0.5 & 0.144 & & & & & & & & & & & & & & & & & \\
\hline size fraction $(\mu \mathrm{m})$ & & $350-400$ & $400-450$ & & & & & & & & & & & & & & & & & \\
\hline no. of individuals & & 2 & 2 & & & & & & & & & & & & & & & & & \\
\hline average size $(\mu \mathrm{m})$ & & 375.5 & 429 & & & & & & & & & & & & & & & & & \\
\hline average weight ( $\mu \mathrm{g})$ & & 5.833 & 11 & & & & & & & & & & & & & & & & & \\
\hline $\mathrm{SD}(\mu \mathrm{g})$ & & 0.289 & 0 & & & & & & & & & & & & & & & & & \\
\hline size fraction $(\mu \mathrm{m})$ & & $400-450$ & $450-500$ & & & & & & & & & & & & & & & & & \\
\hline no. of individuals & & 1 & & & & & & & & & & & & & & & & & & \\
\hline average size $(\mu \mathrm{m})$ & & 447 & 477 & & & & & & & & & & & & & & & & & \\
\hline average weight ( $\mu \mathrm{g})$ & & 9.333 & 7.333 & & & & & & & & & & & & & & & & & \\
\hline $\mathrm{SD}(\mu \mathrm{g})$ & & 0.577 & 0.577 & & & & & & & & & & & & & & & & & \\
\hline \multicolumn{21}{|l|}{ O. universa } \\
\hline size fraction $(\mu \mathrm{m})$ & $350-400$ & $250-300$ & $500-550$ & $400-450$ & & $450-500$ & & $300-350$ & $350-400$ & $700-750$ & $650-700$ & & $700-750$ & $450-500$ & $300-350$ & $400-450$ & $400-450$ & $400-450$ & $450-500$ & $350-400$ \\
\hline no. of individuals & 3 & 1 & 1 & 2 & & 1 & & 1 & 1 & 1 & 1 & & 2 & 1 & 1 & 1 & 1 & 1 & 2 & 1 \\
\hline average size $(\mu \mathrm{m})$ & 390 & 286 & 501 & 445 & & 479 & & 342 & 398 & 719 & 687 & & 722.5 & 452 & 347 & 444 & 441 & 441 & 479.5 & 377 \\
\hline average weight $(\mu \mathrm{g})$ & 17.667 & 7 & 20.667 & 11.667 & & 31 & & 3 & 6.333 & 47 & 43 & & 24.167 & 14.333 & 5.333 & 18.667 & 24.333 & 22.667 & 31 & 20 \\
\hline $\mathrm{SD}(\mu \mathrm{g})$ & 0.333 & 0 & 0.577 & 0.289 & & 1 & & 0 & 0.577 & 1 & 0 & & 0.289 & 0.577 & 0.577 & 0.577 & 0.577 & 0.577 & 0.5 & 1 \\
\hline size fraction $(\mu \mathrm{m})$ & $400-450$ & & & $450-500$ & & $500-550$ & & $350-400$ & $500-550$ & & $750-800$ & & $750-800$ & & $350-400$ & $550-600$ & $450-500$ & & $550-600$ & $400-450$ \\
\hline no. of individuals & 1 & & & & & 2 & & & 1 & & 1 & & 1 & & 1 & 1 & 1 & & 1 & 2 \\
\hline average size $(\mu \mathrm{m})$ & 444 & & & 479 & & 539.5 & & 373.667 & 539 & & 781 & & 785 & & 369 & 559 & 455 & & 571 & 425.5 \\
\hline average weight $(\mu \mathrm{g})$ & 28.667 & & & 22.889 & & 33.833 & & 6.556 & 25.667 & & 54.667 & & 53.667 & & 6.667 & 34.333 & 23.667 & & 45 & 24.167 \\
\hline $\mathrm{SD}(\mu \mathrm{g})$ & 1.155 & & & 0.192 & & 0.289 & & 0.385 & 0.577 & & 0.577 & & 0.577 & & 0.577 & 0.577 & 0.577 & & 1 & 0.577 \\
\hline size fraction $(\mu \mathrm{m})$ & $500-550$ & & & $650-700$ & & $600-650$ & & $400-450$ & & & & & & & $400-450$ & $600-650$ & $500-550$ & & $650-700$ & $450-500$ \\
\hline no. of individuals & 1 & & & & & 1 & & 1 & & & & & & & 1 & 2 & 6 & & 2 & 1 \\
\hline average size $(\mu \mathrm{m})$ & 527 & & & 656 & & 603 & & 439 & & & & & & & 412 & 640 & 534.5 & & 676 & 482 \\
\hline average weight $(\mu \mathrm{g})$ & 36.667 & & & 25.667 & & 50.667 & & 13.667 & & & & & & & 13 & 54.833 & 30.278 & & 84.333 & 35 \\
\hline $\mathrm{SD}(\mu \mathrm{g})$ & 0.577 & & & 1.155 & & 0.577 & & 1.155 & & & & & & & 0 & 0.289 & 0.096 & & 0.289 & 1 \\
\hline size fraction $(\mu \mathrm{m})$ & $550-600$ & & & & & $650-700$ & & $450-500$ & & & & & & & $450-500$ & $650-700$ & & & $750-800$ & $500-550$ \\
\hline no. of individuals & & & & & & & & 1 & & & & & & & 1 & 2 & & & 1 & 1 \\
\hline average size $(\mu \mathrm{m})$ & 578.667 & & & & & 674.333 & & 460 & & & & & & & 476 & 656.5 & & & 762 & 509 \\
\hline average weight $(\mu \mathrm{g})$ & 45.389 & & & & & 47.889 & & 17.333 & & & & & & & 24 & 63.333 & & & 136 & 42 \\
\hline $\mathrm{SD}(\mu \mathrm{g})$ & 0.096 & & & & & 0.096 & & 1.155 & & & & & & & 1 & 0.289 & & & 0 & 0 \\
\hline size fraction $(\mu \mathrm{m})$ & $600-650$ & & & & & $700-750$ & & & & & & & & & $500-550$ & & & & & \\
\hline no. of individuals & & & & & & 2 & & & & & & & & & & & & & & \\
\hline average size $(\mu \mathrm{m})$ & 605 & & & & & 720 & & & & & & & & & 527.333 & & & & & \\
\hline average weight $(\mu \mathrm{g})$ & 48.667 & & & & & 34 & & & & & & & & & 21.778 & & & & & \\
\hline $\mathrm{SD}(\mu \mathrm{g})$ & 0.577 & & & & & 0 & & & & & & & & & 0.192 & & & & & \\
\hline size fraction $(\mu \mathrm{m})$ & $650-700$ & & & & & $750-800$ & & & & & & & & & $550-600$ & & & & & \\
\hline no. of individuals & & & & & & 1 & & & & & & & & & 1 & & & & & \\
\hline average size $(\mu \mathrm{m})$ & 651 & & & & & 772 & & & & & & & & & 570 & & & & & \\
\hline average weight $(\mu \mathrm{g})$ & 50.667 & & & & & 48 & & & & & & & & & 17.333 & & & & & \\
\hline $\mathrm{SD}(\mu \mathrm{g})$ & 0.577 & & & & & 1 & & & & & & & & & 1.528 & & & & & \\
\hline size fraction $(\mu \mathrm{m})$ & & & & & & & & & & & & & & & $600-650$ & & & & & \\
\hline no. of individuals & & & & & & & & & & & & & & & 1 & & & & & \\
\hline $\begin{array}{l}\text { average size }(\mu \mathrm{m}) \\
\text { and }\end{array}$ & & & & & & & & & & & & & & & 625 & & & & & \\
\hline average weight ( $\mu \mathrm{g})$ & & & & & & & & & & & & & & & 23 & & & & & \\
\hline $\mathrm{SD}(\mu \mathrm{g})$ & & & & & & & & & & & & & & & 0 & & & & & \\
\hline size fraction $(\mu \mathrm{m})$ & & & & & & & & & & & & & & & $650-700$ & & & & & \\
\hline $\begin{array}{l}\text { no. of individuals } \\
\text { notis }\end{array}$ & & & & & & & & & & & & & & & 2 & & & & & \\
\hline average size ( $\mu \mathrm{m})$ & & & & & & & & & & & & & & & 654.5 & & & & & \\
\hline average weight $(\mu \mathrm{g})$ & & & & & & & & & & & & & & & 31.167 & & & & & \\
\hline $\mathrm{SD}(\mu \mathrm{g})$ & & & & & & & & & & & & & & & 0.289 & & & & & \\
\hline
\end{tabular}




\section{The Supplement related to this article is available online at doi:10.5194/bg-14-2245-2017-supplement.}

Competing interests. The authors declare that they have no conflict of interest.

Acknowledgements. We thank the captain and crew of the Spanish R/V Ángeles Alvariño for supporting the sampling of this study, M. F. G. Weinkauf, F. Lirer, and an anonymous referee for the constructive comments that greatly helped to improve the manuscript, M. Acevedo and U. Tilves for sample collection, E. Xicoy Espaulella for helping with sample processing, and M. Giani for providing the nutrient data. This work was funded by the EU-FP7 "Mediterranean Sea Acidification in a changing climate" project (MedSeA; grant agreement 265103), the CALMED project (CTM2016-79547-R), and the Generalitat de Catalunya (MERS, 2014 SGR - 1356). This work is contributing to the ICTA "Unit of Excellence" (MinECo, MDM2015-0552).

Edited by: M. Kienast

Reviewed by: M. F. G. Weinkauf, F. Lirer, and one anonymous referee

\section{References}

Aldridge, D., Beer, C. J., and Purdie, D. A.: Calcification in the planktonic foraminifera Globigerina bulloides linked to phosphate concentrations in surface waters of the North Atlantic Ocean, Biogeosciences, 9, 1725-1739, doi:10.5194/bg-9-17252012, 2012.

André, A., Weiner, A., Quillévéré, F., Aurahs, R., Morard, R., Douady, C. J., Garidel-Thoron, T., Escarguel, G., de Vargas, C., and Kučera, M.: The cryptic and the apparent reversed: lack of genetic differentiation within the morphologically diverse plexus of the planktonic foraminifer Globigerinoides sacculifer, Paleobiology, 39, 21-39, 2013.

André, A., Quillévéré, F., Morard, R., Ujiié, Y., Escarguel, G., de Vargas, C., de Garidel-Thoron, T., and Douady, C. J.: SSU rDNA divergence in planktonic Foraminifera: Molecular taxonomy and biogeographic implications, PLoS One, 9, e104641, doi:10.1371/journal.pone.0104641, 2014.

Arnold, A. J. and Parker, W. C.: Biogeography of planktonic foraminifera, in: Modern Foraminifera, edited by: Gupta, B., Kluwer Academic Publishers, Dordrecht, the Netherlands, 103122, 1999.

Aurahs, R., Treis, Y., Darling, K., and Kucera, M.: A revised taxonomic and phylogenetic concept for the planktonic foraminifer species Globigerinoides ruber based on molecular and morphometric evidence, Mar. Micropaleontol., 79, 1-14, 2011.

Auras-Schudnagies, A., Kroon, D., Ganssen, G., Hemleben, Ch., and van Hinte, J. E.: Distributional pattern of planktonic foraminifers and pteropods in surface waters and top core sediments of the Red Sea, and adjacent areas controlled by the monsoonal regime and other ecological factors, Deep-Sea Res., 36, 1515-1533, 1989.
Bárcena, M. A., Flores, J. A., Sierro, F. J., Pérez-Folgado, M., Fabres, J., Calafat, A., and Canals, M.: Planktonic response to main oceanographic changes in the Alboran Sea (Western Mediterranean) as documented in sediment traps and surface sediments, Mar. Micropaleontol., 53, 423-445, 2004.

Bé, A. W. H.: An ecological, zoogeographic and taxonomic review of recent planktonic foraminifera, in: Oceanic Micropalaeontology, edited by: Ramsay, A. T. S., 1, 1-100, Academic Press, London, New York, San Francisco, 1977.

Bé, A. W. H. and Tolderlund, D. S.: Distribution and ecology of living planktonic foraminifera in surface waters of the Atlantic and Indian Oceans, in: The micropaleontology of oceans, edited by: Funnel, B. M. and Riedel, W. R., Cambridge University Press, London, UK, 105-149, 1971.

Bé, A. W. H., Harrison, S. M., and Lott, L.: Orbulina universa (d'Orbigny) in the Indian Ocean, Micropaleontology, 19, 150192, 1973.

Beer, C. J., Schiebel, R., and Wilson, P. A.: Testing planktic foraminiferal shell weight as a surface water $\left[\mathrm{CO}_{3}^{2-}\right]$ proxy using plankton net samples, Geol. Soc. Am., 38, 103-106, 2010a.

Beer, C. J., Schiebel, R., and Wilson, P. A.: Technical Note: On methodologies for determining the size-normalised weight of planktic foraminifera, Biogeosciences, 7, 2193-2198, doi:10.5194/bg-7-2193-2010, 2010 b.

Bijma, J., Faber, W. W., and Hemleben, Ch.: Temperature and salinity limits for growth and survival of some planktonic foraminifers in laboratory cultures, J. Foramin. Res., 20, 95-116, doi:10.2113/gsjfr.20.2.95, 1990.

Bijma, J., Hemleben, Ch., and Wellnitz, K.: Lunar-influenced carbonate flux of the planktic foraminifer Globigerinoides sacculifer (Brady) from the central Red Sea, Deep-Sea Res. Pt. I, 41, 511-530, 1994.

Boltovskoy, E. and Lena, H. A.: On the decomposition of the protoplasm and the sinking velocity of the planktonic foraminifers, Int. Rev. Hydroviol., 55, 797-804, 1970.

Boltovskoy, E., Boltovskoy, D., and Brandini, F.: Planktonic foraminifera from south-western Atlantic epipelagic waters: abundance, distribution and year-to-year variations, J. Mar. Biol. Assoc. UK, 79, 203-213, 2000.

Brown, E., Colling, A., Park, D., Phillips, J., Rothery, D., and Wright, J.: Ocean circulation, 2nd Edn., the Open University, Walton Hall, Milton Keynes MK7 6AA, and ButterworthHeinemann, UK, 2001.

Caromel, A. G. M., Schmidt, D. N., Phillips, J. C., and Rayfield, E. J.: Hydrodynamic constraints on the evolution and ecology of planktic foraminifera, Mar. Micropaleontol., 106, 69-78, 2014.

Cifelli, R.: Planktonic foraminifera from the Mediterranean and adjacent Atlantic waters (Cruise 49 of the Atlantis II, 1969), J. Foramin. Res., 4, 171-183, 1974.

Cossarini, G., Lazzari, P., and Solidoro, C.: Spatiotemporal variability of alkalinity in the Mediterranean Sea, Biogeosciences, 12, 1647-1658, doi:10.5194/bg-12-1647-2015, 2015.

Cramp, A., Collins, M., and West, R.: Late Pleistocene-Holocene sedimentation in the NW Aegean Sea: A palaeoclimatic palaeoceanographic reconstruction, Palaeogeogr. Palaeocl., 68, 61-77, 1988.

d'Orbigny, A. D.: Tableau méthodique de la classe des céphalopodes, Ann. Sci. Nat., Paris, Ser., 1, 96-314, 1826. 
Darling, K. F. and Wade, C. M.: The genetic diversity of planktic Foraminifera and the global distribution of ribosomal RNA genotypes, Mar. Micropaleontol., 67, 216-238, 2008.

de Castro Coppa, M. G., Zei, M. M., Placella, B., Sgarella, F., and Ruggiero, E. T.: Distribuzione stagionale e verticale dei foraminiferi planctonici del Golfo di Napoli, Boll. Soc. Natur. Napoli, 89, 1-25, 1980.

de Moel, H., Ganssen, G. M., Peeters, F. J. C., Jung, S. J. A., Kroon, D., Brummer, G. J. A., and Zeebe, R. E.: Planktic foraminiferal shell thinning in the Arabian Sea due to anthropogenic ocean acidification?, Biogeosciences, 6, 1917-1925, doi:10.5194/bg-61917-2009, 2009.

de Vargas, C., Norris, R., Zaninetti, L., Gibb, S. W., and Pawlowski, J.: Molecular evidence of cryptic speciation in planktonic foraminifers and their relation to oceanic provinces, P. Natl. Acad. Sci. USA, 96, 2864-2868, 1999.

Dickson, A. G. and Millero, F. J.: A comparison of the equilibrium constants for the dissociation of carbonic acid in seawater media, Deep-Sea Res., 34, 1733-1743, 1987.

Field, D. B., Baumgartner, T. R., Charles, C. D., Ferreira-Bartrina, V., and Ohman, M. D.: Planktonic foraminifera of the California Current reflect 20th-century warming, Science, 311, 63-66, 2006.

Gemayel, E., Hassoun, A. E. R., Benallal, M. A., Goyet, C., Rivaro, P., Abboud-Abi Saab, M., Krasakopoulou, E., Touratier, F., and Ziveri, P.: Climatological variations of total alkalinity and total dissolved inorganic carbon in the Mediterranean Sea surface waters, Earth Syst. Dynam., 6, 789-800, doi:10.5194/esd-6-7892015, 2015.

Glaçon, G., Vergnaud Grazzini, C., and Sigal, J.: Premiers resultants d'une série d'observations saisonnières des foraminifères du plankton méditerranéen, in: Procceedings of the 2nd Plankton Conference, 1970, Rome, 555-581, 1971.

Goldstein, S. T.: Foraminifera: A biological overview, in: Modern Foraminifera, edited by: Gupta, B., Kluwer Academic Publishers, Dordrecht, Netherlands, 37-55, 1999.

Goyet, C., Hassoun, A. E. R., and Gemayel, E.: Carbonate system during the May 2013 MedSeA cruise, doi:10.1594/PANGAEA.841933, 2015.

Grasshoff, K., Ehrhardt, M., and Kremling, K.: Methods of seawater analysis, 3rd Edn., Verlag Chemie, Weinheim, Deerfield Beach, Florida, Basel, 1999.

Hassoun, A. E. R., Gemayel, E., Krasakopoulou, E., Goyet, C., Saab, M. A., Ziveri, P., Touratier, F., Guglielmi, V., and Falco, C.: Modeling of the total alkalinity and the total inorganic carbon in the Mediterranean Sea, J. Water Res. Ocean Sci., 4, 24-32, 2015a.

Hassoun, A. E. R., Guglielmi, V., Gemayel, E., Goyet, C., Saab, M. A., Giani, M., Ziveri, P., Ingrosso, G., and Touratier, M.: Is the Mediterranean Sea circulation in a steady state, J. Water Res. Ocean Sci., 4, 6-17, 2015 b.

Hemleben, Ch., Spindler, M., and Anderson, O. R.: Modern Planktonic Foraminifera, Springer-Verlag, New York, Berlin, Heidelberg, 363 pp., 1989.

Hernández-Almeida, I., Bárcena, M. A., Flores, J. A., Sierro, F. J., Sanchez-Vidal, A., and Calafat, A.: Microplankton response to environmental conditions in the Alboran Sea (Western Mediterranean): One year sediment trap record, Mar. Micropaleontol., 78, 14-24, 2011.
Jonkers, L. and Kucera, M.: Global analysis of seasonality in the shell flux of extant planktonic Foraminifera, Biogeosciences, 12, 2207-2226, doi:10.5194/bg-12-2207-2015, 2015.

Köhler-Rink, S. and Kühl, M.: The chemical microenvironment of the symbiotic planktonic foraminifer Orbulina universa, Mar. Biol. Res., 1, 68-78, 2005.

Kuroyanagi, A. and Kawahata, H.: Vertical distribution of living planktonic foraminifera in the seas around Japan, Mar. Micropaleontol., 53, 173-196, 2004.

Lewis, E., Wallace, D., and Allison, L. J.: Program developed for $\mathrm{CO}_{2}$ system calculations, Tennessee: Carbon Dioxide Information Analysis Center, managed by: Lockheed Martin Energy Research Corporation for the US Department of Energy, 1998.

Lirer, F., Sprovieri, M., Ferraro, L., Vallefuoco, M., Capotondi, L., Cascella, A., Petrosino, P., Insinga, D. D., Pelosi, N., Tamburrino, S., and Lubritto, C.: Integrated stratigraphy for the Late Quaternary in the eastern Tyrrhenian Sea, Quaternary Int., 292, 71-85, 2013.

Margaritelli, G., Vallefuoco, M., Di Rita, F., Capotondi, L., Bellucci, L. G., Insinga, D. D., Petrosino, P., Bonomo, S., Cacho, I., Cascella, A., Ferraro, L., Florindo, F., Lubritto, C., Lurcock, P. C., Magri, D., Pelosi, N., Rettori, R., and Lirer, F.: Marine response to climate changes during the last five millennia in the central Mediterranean Sea, Global Planet. Change, 142, 53-72, 2016.

Marshall, B. J., Thunell, R. C., Henehan, M. J., Astor, Y., and Wejnert, K. E.: Planktonic foraminiferal area density as a proxy for carbonate ion concentration: A calibration study using the Cariaco Basin ocean time series, Paleoceanography, 28, 363-376, 2013.

Marshall, B. J., Thunell, R. C., Spero, H. J., Henehan, M. J., Lorenzoni, L., and Astor, Y.: Morphometric and stable isotopic differentiation of Orbulina universa morphotypes from the Cariaco Basin, Venezuela, Mar. Micropaleontol., 120, 46-64, 2015.

Mehrbach, C.: Measurement of the apparent dissociation constants of carbonic acid in seawater at atmospheric pressure, M.S., Oregon State University, Oregon, USA, 1973.

Mohan, R., Shetye, S. S., Tiwari, M., and Anilkumar, N.: Secondary calcification of planktic foraminifera from the Indian sector of Southern Ocean, Acta Geol. Sin.-Engl., 89, 27-37, 2015.

Mojtahid, M., Manceau, R., Schiebel, R., Hennekam, R., and de Lange, G. J.: Thirteen thousand years of southeastern Mediterranean climate variability inferred from an integrative planktic foraminiferal-based approach: Holocene climate in the SE Mediterranean, Paleoceanography, 30, 402-422, doi:10.1002/2014PA002705, 2015.

Morard, R., Quillévéré, F., Escarguel, G., Ujiie, Y., Garidel-Thoron, T., Norris, R. D., and de Vargas, C.: Morphological recognition of cryptic species in the planktonic foraminifer Orbulina universa, Mar. Micropaleontol., 71, 148-165, 2009.

Morard, R., Qullévéré, F., Escarguel, G., Garidel-Thoron, T., de Vargas, C., and Kučera, M.: Ecological modeling of the temperature dependence of cryptic species of planktonic foraminifera in the Southern Hemisphere, Palaeogeogr. Palaeocl., 391, 13-33, 2013.

Mortyn, P. G. and Charles, C. D.: Planktonic foraminiferal depth habitat and $\delta^{18} \mathrm{O}$ calibrations: plankton tow results from the Atlantic sector of the Southern Ocean, Paleoceanography, 18, 1037, doi:10.1029/2001PA000637, 2003. 
Movellan, A., Schiebel, R., Zubkov, M. V., Smyth, A., and Howa, H.: Protein biomass quantification of unbroken individual foraminifers using nano-spectrophotometry, Biogeosciences, 9, 3613-3623, doi:10.5194/bg-9-3613-2012, 2012.

Moy, A. D., Howard, W. R., Bray, S. G., and Trull, T. W.: Reduced calcification in modern Southern Ocean planktonic Foraminifera, Nat. Geosci. 2, 276-280, doi:10.1038/ngeo460, 2009.

NASA Goddard Space Flight Center: Ocean Ecology Laboratory, Ocean Biology Processing Group: MODIS-Aqua L2 Data; NASA Goddard Space Flight Center, Ocean Ecology Laboratory, Ocean Biology Processing Group, available at: http://oceandata. sci.gsfc.nasa.gov/, last access: 6 June 2013.

Ottens, J. J.: April and August Northeast Atlantic surface water masses reflected in planktic foraminifera, Neth. J. Sea Res., 28, 261-283, 1992.

Pados, T. and Spielhagen, R. F.: Species distribution and depth habitat of recent planktic foraminifera in Fram Strait, Artic Ocean, Polar Res., 33, 22483, doi:10.3402/polar.v33.22483, 2014.

Parker, F. L.: Distribution of planktonic foraminiferal in some Mediterranean sediments, Pap. Mar. Biol. Oceanogr., 3, 204211, 1955.

Pettersson, H.: The Swedish Deep-Sea Expedition, 1947-48, DeepSea Res., 1, 17-24, 1953.

Posgay, J. A.: The MARMAP Bongo zooplankton samplers, J. Northw. Atl. Fish. Sci., 1, 91-99, 1980.

Pujol, C. and Vergnaud Grazzini, C.: Distribution patterns of live planktic foraminifers as related to regional hydrography and productive systems of the Mediterranean Sea, Mar. Micropaleontol., 25, 187-217, 1995.

Rao, K. K., Jayalakshmy, K. V., and Kutty, M. K.: Ecology and distribution of recent planktonic foraminifera in eastern part of Arabian Sea, Indian J. Mar. Sci., 20, 25-35, 1991.

Rebotim, A., Voelker, A. H. L., Jonkers, L., Waniek, J. J., Meggers, H., Schiebel, R., Fraile, I., Schulz, M., and Kucera, M.: Factors controlling the depth habitat of planktonic foraminifera in the subtropical eastern North Atlantic, Biogeosciences, 14, 827-859, doi:10.5194/bg-14-827-2017, 2017.

Rigual-Hernández, A., Sierro, F. J., Bárcena, M. A., Flores, J. A., and Heussner, S.: Seasonal and interannual changes of planktic foraminiferal fluxes in the Gulf of Lions (NW Mediterranean) and their implications for paleoceanographic studies: Two 12year sediment trap records, Deep-Sea Res. Pt. I, 66, 26-40, 2012.

Rio, D., Sprovieri, R., Thunell, R., Vergnaud Grazzini, C., and Glaçon, G.: Pliocene-Pleistocene paleoenvironmental history of the western Mediterranean: A synthesis of ODP site 653 results, Proc. Ocean Drill Prog. Sci. Results, 107, 695-704, 1990.

Rohling, E., Ramadan, A., Casford, J., Hayes, A., and Hoogakker, B.: The marine environment: present and past, in: The physical geography of the Mediterranean, edited by: Woodward, J., Oxford University Press, New York, USA, 33-67, 2009.

Rohling, E. J., Sprovieri, M., Cane, T., Casford, J. S. L., Cooke, S., Bouloubassi, I., Emeis, K. C., Schiebel, R., Rogerson, M., Hayes, A., Jorissen, F. J., and Kroon, D.: Reconstructing past planktic foraminiferal habitats using stable isotope data: A case history for Mediterranean sapropel S5, Mar. Micropaleontol., 50, 89-123, doi:10.1016/S0377-8398(03)00068-9, 2004.

Rohling, E. J., Marino, G., and Grant, K. M.: Mediterranean climate and oceanography, and the periodic development of anoxic events (sapropels), Earth Sci., 143, 62-97, 2015.
Schiebel, R. and Hemleben, Ch.: Modern planktic foraminifera, Palaeont. Z., 79, 135-148, 2005.

Schiebel, R., Hiller, B., and Hemleben, Ch.: Impacts of storms on recent planktic foraminiferal test production and $\mathrm{CaCO}_{3}$ flux in the North Atlantic at $47^{\circ} \mathrm{N}, 20^{\circ} \mathrm{W}$ (JGOFS), Mar. Micropaleontol., 26, 115-129, 1995.

Schiebel, R., Waniek, J., Zeltner, A., and Alves, M.: Impact of the Azores Front on the distribution of planktic foraminifers, shelled gastropods, and coccolithophorids, Deep-Sea Res., 49, 40354050, 2002.

Schiebel, R., Barker, S., Lendt, R., Thomas, H., and Bollmann, J.: Planktic foraminiferal dissolution in the twilight zone, Deep-Sea Res. Pt. II, 54, 676-686, 2007.

Schlitzer, R.: Ocean Data View, available at: http://odv.awi.de, last access: 15 June 2016.

Schmidt, D. N., Thierstein, H. R., Bollmann, J., and Schiebel, R.: Abiotic forcing of plankton evolution in the Cenozoic, Science, 303, 207-210, 2004.

Schmuker, B. and Schiebel, R.: Spatial and temporal distribution of planktic foraminifers in the eastern Caribbean, Mar. Micropaleontol., 46, 387-403, 2002.

Schneider, A., Wallace, D. W. R., and Körtzinger, A.: Alkalinity of the Mediterranean Sea, Geophys. Res. Lett., 34, L15608, doi:10.1029/2006GL028842, 2007.

Schneider, C. A., Rasband, W. S., and Eliceiri, K. W.: NIH Image to ImageJ: 25 years of image analysis, Nat. Methods, 9, 671-675, 2012.

Shackleton, N.: Depth of pelagic foraminifera and isotopic changes in Pleistocene oceans, Nature, 218, 79-80, doi:10.1038/218079a0, 1968.

Sousa, S. H. M., Godoi, S. S., Amaral, P. G. C., Vicente, T. M., Martins, M. V. A., Sorano, M. R. G. S., Gaeta, S. A., Passos, R. F., and Mahiques, M. M.: Distribution of living planktonic foraminifera in relation to oceanic processes on the southeastern continental Brazilian margin $\left(23^{\circ} \mathrm{S}-25^{\circ} \mathrm{S}\right.$ and $\left.40^{\circ} \mathrm{W}-44^{\circ} \mathrm{W}\right)$, Cont. Shelf Res., 89, 76-87, 2014.

Spero, H. J.: Ultrastructural examination of chamber morphogenesis and biomineralization in the planktonic foraminifer Orbulina universa, Mar. Biol., 99, 9-20, 1988.

Spero, H. J., Eggins, S. M., Russell, A. D., Vetter, L., Kilburn, M. R., and Hönisch, B.: Timing and mechanism for intratest $\mathrm{Mg} / \mathrm{Ca}$ variability in a living planktic foraminifer, Earth Planet Sc. Lett., 409, 32-42, doi:10.1016/j.eps1.2014.10.030, 2015.

Spezzaferri, S., Kucera, M., Pearson, P. N., Wade, B. S., Rappo, S., Poole, C. R., Morard, R., and Stalder, C.: Fossil and genetic evidence for the polyphyletic nature of the planktonic foraminifera "Globigerinoides", and description of the new genus Trilobatus, PLOS One, 10, doi:10.1371/journal.pone.0128108, 2015.

Thunell, R. C.: Distribution of recent planktonic foraminifera in surface sediments of the Mediterranean Sea, Mar. Micropaleontol., 3, 147-173, 1978.

van Raden, U. J., Groeneveld, J., Raitzsch, M., and Kučera, M.: $\mathrm{Mg} / \mathrm{Ca}$ in the planktonic foraminifera Globorotalia inflata and Globigerinoides bulloides from Western Mediterranean plankton tow and core top samples, Mar. Micropaleontol., 78, 101-112, 2011.

Vergnaud Grazzini, C., Glaçon, C., Pierre, C., Pujol, C., and Urrutiaguer, M. J.: Foraminifères planctoniques de Méditerranée en 
fin d'été. Relations avec les structures hydrologiques, Mem. Soc. Geol. Ital., 36, 175-188, 1986.

Weiner, A. K. M., Weinkauf, M. F. G., Kurasawa, A., Darling, K. F., and Kucera, M.: Genetic and morphometric evidence for parallel evolution of the Globigerinella calida morphotype, Mar. Micropaleontol., 114, 19-35, 2015.

Weinkauf, M. F. G., Moller, T., Koch, M. C., and Kucera, M.: Calcification intensity in planktonic Foraminifera reflects ambient conditions irrespective of environmental stress, Biogeosciences, 10, 6639-6655, doi:10.5194/bg-10-6639-2013, 2013.

Weinkauf, M. F. G., Kunze, J. G., Waniek, J. J., and Kučera, M.: Seasonal variation in shell calcification of planktonic foraminifera in the NE Atlantic reveals species-specific response to temperature, productivity, and optimum growth conditions, PLOS One, 11, e0148363, doi:10.1371/journal.pone.0148363, 2016.
Yáñez, M. V., Martínez, M. C. G., and Ruiz, F. M.: Cambio climático en el Mediterráneo español, edited by: Instituto Español de Oceanografía, Ministerio de Educación y Ciencia, Madrid, Spain, 2010.

Žarić, S., Donner, B., Fischer, G., Mulitza, S., and Wefer, G.: Sensitivity of planktic foraminifera to sea surface temperature and export production as derived from sediment trap data, Mar. Micropaleontol., 55, 75-105, 2005.

Zeebe, R. E.: History of Seawater Carbonate Chemistry, Atmospheric $\mathrm{CO}_{2}$ and Ocean Acidification, Annu. Rev. Earth Planet. Sc., 40, 141-165, 2012.

Ziveri, P. and Grelaud, M.: Physical oceanography during Ángeles Alvariño cruise MedSeA2013, Universitat Autònoma de Barcelona, doi:10.1594/PANGAEA.846067, 2015. 